\title{
MICROSSISTEMAS DE ANÁLISES QUÍMICAS. INTRODUÇÃO, TECNOLOGIAS DE FABRICAÇÃO, INSTRUMENTAÇÃO E APLICAÇÕES
}

\author{
Wendell Karlos Tomazelli Coltro, Evandro Piccin e Emanuel Carrilho* \\ Instituto de Química de São Carlos, Universidade de São Paulo, CP 780, 13560-970 São Carlos - SP, Brasil \\ Dosil Pereira de Jesus e José Alberto Fracassi da Silva \\ Instituto de Química, Universidade Estadual de Campinas, CP 6154, 13084-971 Campinas - SP, Brasil \\ Heron Domingues Torres da Silva e Claudimir Lúcio do Lago \\ Instituto de Química, Universidade de São Paulo, CP 26077, 05513-970 São Paulo - SP, Brasil
}

Recebido em 9/11/06; aceito em 2/3/07; publicado na web em 9/11/07

\begin{abstract}
MICRO CHEMICAL ANALYSIS SYSTEMS. INTRODUCTION, FABRICATION TECHNOLOGIES, INSTRUMENTATION AND
APPLICATIONS. The amazing world of micro total analysis systems has provided a true revolution in analytical chemistry in recent years. The application of the microfluidic devices for chemical and biochemical processing has attracted considerable interest due to its advantages such as reduced sample and reagent consumption, processing time, energy, waste, cost, and portability. The aim of the present report is to disseminate the state of the art related to the miniaturization science in Analytical Chemistry. Historical progress, microfabrication technologies, required instrumentation and applications of the $\mu \mathrm{TAS}$ are presented in the current article, with special attention to the Brazilian contributions.
\end{abstract}

Keywords: micro total analysis systems; microfabrication; miniaturization.

\section{INTRODUÇÃO}

A comunidade científica tem observado, nas últimas décadas, o surgimento, o crescimento e a consolidação de uma nova tendência mundial: a miniaturização. Em diferentes ramificações da ciência é comum, e cada vez mais necessário, o uso de dispositivos miniaturizados. Na Química Analítica não é diferente, e o uso de sistemas miniaturizados é uma realidade em âmbito mundial. Este trabalho visa a divulgação do estado da arte deste micro-mundo analítico para a comunidade científica nacional. Os principais aspectos relacionados à evolução histórica, incluindo os efeitos e benefícios da miniaturização, tecnologias de microfabricação, instrumentação e algumas aplicações realizadas em sistemas microfabricados são abordados nesta revisão. Obviamente, muitas das informações estarão condensadas no texto. No entanto, há na literatura artigos de revisão que podem auxiliar como material para uma leitura complementar e mais aprofundada ${ }^{1-5}$.

\section{Miniaturização}

A miniaturização de dispositivos eletrônicos, a partir da década de 60 , provocou uma verdadeira revolução na eletrônica e na informática. O rápido desenvolvimento de sistemas miniaturizados, nos mais diferentes campos de pesquisas, tem dominado o progresso da tecnologia moderna. Atualmente, a miniaturização de rádio, televisão, gravador, telefone, discos rígidos e microcomputadores é algo comum e presente no cotidiano do ser humano. Nesse contexto, indústrias ligadas a setores como o automobilístico, informática, entretenimento, telecomunicações e medicina têm faturado milhões de dólares na comercialização de seus produtos ${ }^{6,7}$.

Da mesma forma que os microchips eletrônicos revolucionaram o universo dos computadores e da eletrônica, os microchips analíticos têm revolucionado a química analítica nos últimos anos ${ }^{3-5}$. Ini-

*e-mail: emanuel@iqsc.usp.br cialmente, a principal razão para a miniaturização era aumentar o desempenho analítico mais do que reduzir seu tamanho. No entanto, com a mudança da escala macro para a micro, outras vantagens foram obtidas, como a redução do volume de reagentes e amostras (da ordem de pL-nL), baixo custo de fabricação e análise em tempo reduzido ${ }^{8}$.

O primeiro dispositivo analítico miniaturizado foi um sistema de cromatografia em fase gasosa ${ }^{9}$, apresentado na década de 70 . O micro-cromatógrafo foi construído em lâmina circular de silício com diâmetro de $5 \mathrm{~cm}$. Neste substrato, foi construída uma válvula de injeção e uma coluna de separação de $1,5 \mathrm{~m}$ de comprimento. Um detector de condutividade térmica foi fabricado em um outro substrato, sendo posteriormente prensado mecanicamente para integrá-lo ao substrato contendo a coluna de separação. A Figura 1 apresenta uma imagem desse primeiro microdispositivo analítico.

Apesar da capacidade de realizar rápidas separações, o primeiro microdispositivo não foi prontamente aceito pela comunidade científica, devido à falta de experiência tecnológica em métodos de separação. Com isso, pesquisas relacionadas à miniaturização ficaram limitadas, na década de 80 , ao desenvolvimento de micro-bombas, micro-válvulas e sensores químicos².

O renascimento dos microdispositivos analíticos ocorreu no inicio da década de 90, com a apresentação de um microssistema para cromatografia em fase líquida ${ }^{10}$. Esse cromatógrafo foi fabricado em um substrato de silício com dimensões de $5 \times 5 \mathrm{~cm}$ contendo uma coluna tubular aberta, um detector condutométrico e conexões externas para uma bomba de cromatografia líquida e válvulas para aplicação de pressão.

Simultaneamente à apresentação desse microdispositivo, Manz e colaboradores ${ }^{11}$ propuseram o conceito de microssistemas para análises totais, ou simplesmente $\mu$ TAS. Com o desenvolvimento dos $\mu$ TAS, tornou-se possível integrar várias etapas analíticas, como introdução da amostra, pré-tratamento da amostra, reações químicas, separação analítica e detecção em um único dispositivo ${ }^{8,11}$. Devido à idéia de inserir várias etapas, normalmente desenvolvidas 


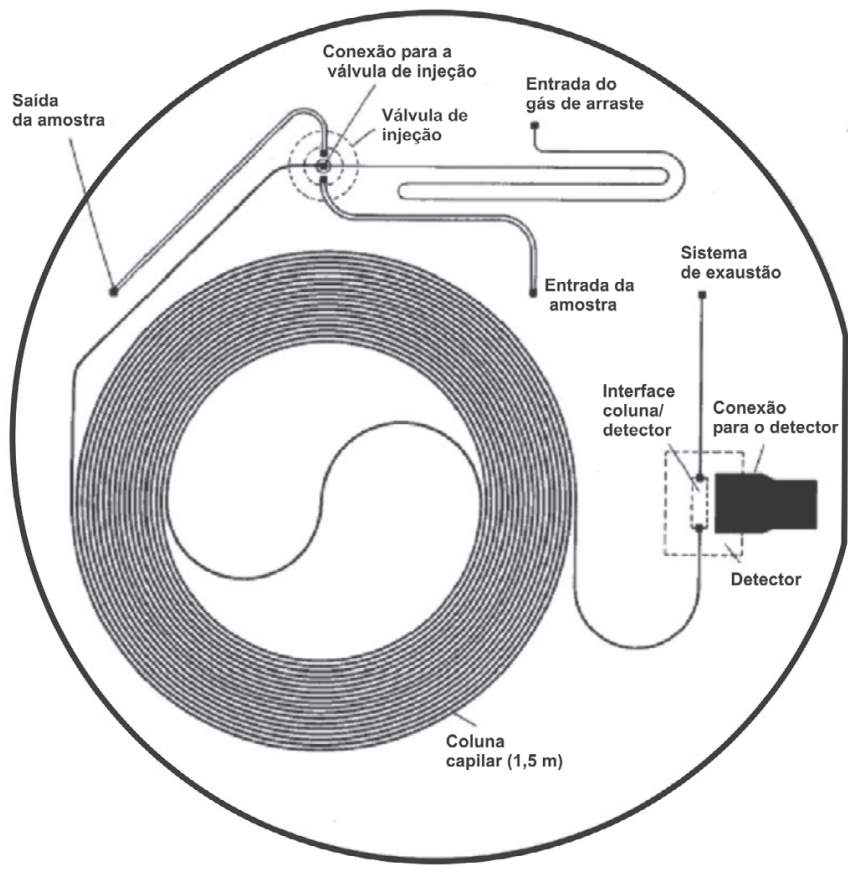

Figura 1. Ilustração do primeiro microssistema para cromatografia em fase gasosa fabricado em substrato de silício, com diâmetro de $5 \mathrm{~cm}$, na Universidade de Stanford, no fim da década de 70. Adaptado da ref. 9

em um laboratório, em um chip, os $\mu$ TAS são também denominados "lab-on-a-chip" (LOC) ${ }^{12}$. Os $\mu$ TAS, ou LOC, transformam informações químicas em sinais elétricos ou ópticos, possibilitando uma fácil automação. Estes aspectos se tornaram relevantes para o campo clínico e ambiental em que o termo "point-of-care" vem sendo utilizado ${ }^{12,13}$. Todos estes fatores, aliados à portabilidade, impulsionaram o desenvolvimento explosivo e maciço dos sistemas analíticos em micro-escala nos últimos anos ${ }^{4,5}$. A Figura 2 apresenta a evolução do número de publicações, relacionada ao uso de microssistemas analíticos, no período de 1990 a 2006, conforme a base de dados da "Web of Science". Muitos destes artigos podem ser encontrados em periódicos específicos para as áreas de micro e nanotecnologia como, por ex., "Journal of Micromechanics and Microengineering, Lab on a Chip, Nano Letters, e Small". Destes, os periódicos "Lab on a Chip" e "Nano Letters" apresentam um elevado fator de impacto (5,2 e 9,8, respectivamente), aspecto que comprova a expansão e importância desta nova fronteira. Além disso, o periódico "Electrophoresis" também publica anualmente uma edição especial sobre miniaturização. Adicionalmente, a "Analytical Chemistry”, principal periódico em Química Analítica, tem publicado bienalmente, desde de 2002, revisões científicas abrangendo a evolução e consolidação destes microssistemas analíticos.

\section{TECNOLOGIAS DE MICROFABRICAÇÃO}

Os $\mu$ TAS, LOC's, microchips ou microdispositivos podem ser fabricados através de tecnologias convencionais ou alternativas, usando diferentes substratos planares. Nas tecnologias convencionais, há a necessidade do uso de uma fonte energética para fazer a transferência da imagem dos microcanais para o substrato utilizado. Tipicamente, essa transferência é primeiramente feita para a superfície de um polímero sensível à radiação utilizada (fotorresiste). A exposição à radiação promove uma interação entre o feixe incidente e o substrato sólido. Conseqüentemente, a absorção de luz ou o espalhamento inelástico das partículas pode afetar a estrutura química do fotorresiste alterando sua solubilidade, permitindo a

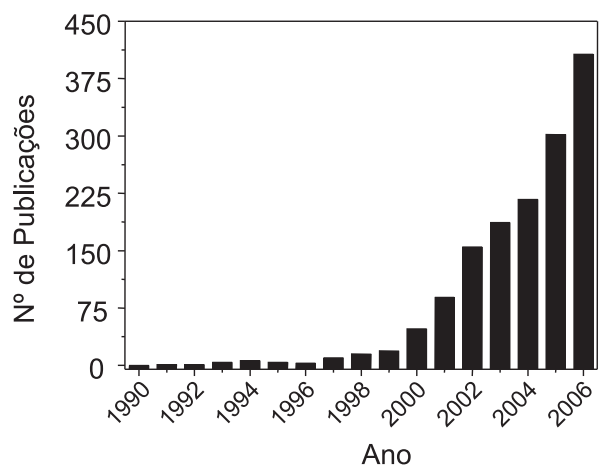

Figura 2. Evolução do número de publicações relacionadas aos microssistemas analíticos entre 1990 e 2006. Pesquisa realizada na "Web of Science" com as seguintes palavras-chave: "lab on a chip, micro total analysis system, microchannels, fluidic microdevices, microfluidic devices, minuaturized system, electrophoresis microchip, microchip electrophoresis, planar chips e micromachined systems"

revelação da imagem fotogravada. Processos litográficos, como a litografia por raios-X, a litografia "soft", a litografia por feixe de elétrons ou a litografia com radiação ultra-violeta (UV), são os mais utilizados ${ }^{14}$.

\section{TECNOLOGIAS CONVENCIONAIS}

\section{Processos fotolitográficos}

A fotolitografia ${ }^{6}$ consiste em transferir estruturas micrométricas, da ordem de 10 a $100 \mu \mathrm{m}$, para um substrato sólido com o auxílio de radiação UV ou raios-X. Este processo foi desenvolvido nas décadas de 70 e 80 pela indústria microeletrônica e foi adaptado para fabricação dos primeiros dispositivos microfluídicos, sendo o silício o substrato pioneiro, devido ao seu amplo emprego na construção de circuitos integrados. Entretanto, em decorrência do seu elevado custo e por possuir propriedades físicas, químicas e elétricas limitadas para este tipo de aplicação, o silício vem sendo substituído por quartzo e vidro. De modo genérico, a Figura 3 apresenta as principais etapas de um processo fotolitográfico para a fabricação de microcanais em vidro. As etapas apresentadas podem ser também utilizadas para a fabricação de microestruturas em outros substratos.

Resumidamente, o processo fotolitográfico consiste na escolha e limpeza do substrato, fotogravação dos microcanais em um polímero fotossensível (fotorresiste), corrosão do substrato e selagem dos microcanais. A limpeza das lâminas de vidro (alcalino, borossilicato ou de sílica), com espessuras inferiores a $10 \mathrm{~mm}$, é realizada com água, detergentes, solventes orgânicos (isopropanol e acetona) e soluções altamente oxidantes, tais como $\mathrm{NH}_{4} \mathrm{OH} / \mathrm{H}_{2} \mathrm{O}_{2}$ e $\mathrm{H}_{2} \mathrm{SO}_{4} / \mathrm{H}_{2} \mathrm{O}_{2}$ (solução piranha). Uma fina camada metálica $(20-100 \mathrm{~nm})$ pode ser depositada sobre o substrato (I), através da técnica de "sputtering" ou evaporação térmica, para atuar como máscara na etapa de corrosão do substrato. Essa camada metálica é, geralmente, constituída de $\mathrm{Cr} / \mathrm{Au}$, sendo que a camada de $\mathrm{Cr}$ é depositada para aumentar a aderência da camada de Au à superfície. Para a etapa de fotogravação, inicialmente uma camada de fotorresiste $(20-50 \mu \mathrm{m})$ é depositada sobre o filme metálico (I) através da técnica de "spin coating" 15 . A radiação $U V$ ou raios- $X$ atinge seletivamente a superfície do fotorresiste após atravessar uma máscara, posicionada entre a fonte de radiação e o substrato (II). As máscaras convencionais, com resolução da ordem de $1 \mu \mathrm{m}$, são fabricadas em uma placa de vidro recoberta por filme fino de $\mathrm{Cr}$, no qual é gravado, também por 
fotolitografia, o padrão dos microcanais a serem transferidos para o substrato. Máscaras com resolução da ordem de $30 \mu \mathrm{m}$ podem ser preparadas em fotolitos, cuja tecnologia é mais rápida e economicamente mais atrativa. De acordo com a natureza do fotorresiste, as cadeias poliméricas nas regiões expostas à radiação podem sofrer uma reticulação e se tornarem insolúveis (fotorresiste negativo) ou podem sofrer uma degradação e se tornarem solúveis (fotorresiste positivo). No processo de microfabricação apresentado na Figura 3 é utilizado fotorresiste negativo, que é o mais utilizado. Dependendo da característica do fotorresiste, há a necessidade de etapas de tratamento térmico antes e depois da fotogravação, de modo a eliminar qualquer presença de solvente e reduzir o estresse intrínseco do material. A imagem fotogravada é revelada (III) com solventes orgânicos específicos para cada tipo de fotorresiste.

Uma vez transferido o padrão dos microcanais para o fotorresiste é realizada a corrosão da camada metálica exposta (IV). Para corrosão do $\mathrm{Au}$ utilizam-se soluções contendo $\mathrm{KI} / \mathrm{I}_{2}$ ou $\mathrm{HCl} / \mathrm{HNO}_{3}$ (água régia) e para corrosão de $\mathrm{Cr}$ solução de $\mathrm{K}_{3} \mathrm{Fe}(\mathrm{CN})_{6}$ ou de $\mathrm{Ce}\left(\mathrm{NH}_{4}\right)_{2}\left(\mathrm{NO}_{3}\right)_{6}$. Após a corrosão da camada metálica, a superfície do substrato torna-se acessível e passa por um processo de corrosão úmida (usando soluções de $\mathrm{HF} / \mathrm{NH}_{4} \mathrm{~F}$ ou $\mathrm{HF} / \mathrm{HNO}_{3}$ ) ou seca (plasma de íons reativos, RIE, "reactive ion etching"), transferindo a imagem dos microcanais para o próprio substrato (V). A profundidade dos canais formados pode ser controlada pelo tempo de corrosão, desde que a taxa de corrosão tenha sido previamente determinada. A taxa de corrosão depende do material do substrato, da composição química da solução, da concentração analítica e da temperatura. Normalmente utilizam-se canais com profundidades de poucas dezenas de micrometros e larguras de até centenas de micrometros. Após a formação dos canais, a camada de fotorresiste é removida com solvente orgânico (acetona), enquanto o filme metálico é retirado com as soluções corrosivas, já mencionadas.

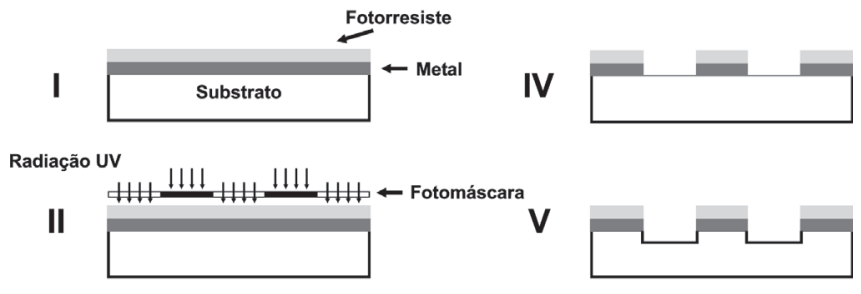

III

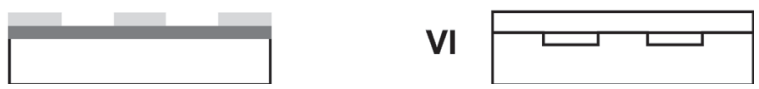

Figura 3. Principais etapas da construção de microdispositivos sobre substrato de vidro através da técnica de fotolitografia: (I) deposição de filmes metálicos e de fotorresiste sobre o substrato; (II) posicionamento da máscara e exposição à radiação $U V$; (III) revelação da imagem fotogravada no fotorresiste; (IV) corrosão das regiões da camada metálica não protegida pelo fotorresiste; (V) corrosão do substrato transferindo a configuração dos microcanais para o vidro e, (VI) remoção das camadas de fotorresiste e metal e selagem do microdispositivo

Existem algumas variações menos usuais desta técnica de microfabricação para vidro, como por ex., a utilização de silício amorfo ou policristalino como máscara para corrosão ${ }^{16-18}$. Este tipo de silício é depositado sobre o vidro por processos envolvendo plas$\mathrm{ma}^{6}$. Em alguns processos, não são usados filmes metálicos como máscara e, nesse caso, apenas o fotorresiste é empregado para essa função ${ }^{19,20}$. Além do uso das máscaras convencionais, estudos recentes têm demonstrado que uma camada de toner, transferida termicamente para a superfície do substrato, pode ser perfeitamente utilizada como máscara para corrosão por via úmida ${ }^{21}$

As técnicas de microfabricação envolvendo silício são semelhantes às empregadas para o vidro, entretanto há algumas diferenças técnicas. Por ex., enquanto que no vidro não é possível realizar corrosão anisotrópica (corrosão preferencial em um sentido), no silício isto é obtido empregando-se solução de $\mathrm{KOH}$ ou corrosão por plasma $^{6,22}$. Outra diferença está na possibilidade da utilização de óxido de silício como máscara, o qual é crescido a partir do próprio substrato por oxidação térmica ${ }^{23,24}$.

Após a transferência dos microcanais para o substrato na etapa de corrosão, é realizada a etapa de selagem (ou vedação) (VI) dos microdispositivos, que consiste em vedar os microcanais empregando-se uma cobertura, a qual pode possuir composição idêntica ou diferente à do substrato. Para dispositivos microfluídicos obtidos por métodos fotolitográficos, em que os substratos geralmente são silício, quartzo ou vidro, a selagem pode ser realizada por processos térmicos ${ }^{6,25}$. Nestes processos, o substrato é colocado em contato com outra lâmina de vidro ou silício e aquecido a temperaturas superiores a $500{ }^{\circ} \mathrm{C}$, ocasionando a formação de ligações covalentes entre o substrato e a cobertura. No entanto, a elevada temperatura empregada neste processo é uma desvantagem, uma vez que pode causar deformações nos perfis dos microcanais. Processos de selagem conduzidos a temperaturas menores vêm sendo desenvolvidos e tem ganhado preferência ${ }^{26}$. Entre estes processos destaca-se a selagem anódica, a qual envolve o aquecimento $\left(200\right.$ a $\left.500{ }^{\circ} \mathrm{C}\right)$ e a simultânea aplicação de uma diferença de potencial (300 a $1000 \mathrm{~V})$ entre o substrato e a cobertura. A selagem anódica é empregada para selagem vidro-silício, silício-silício e silício-metal. Outras técnicas de selagem a baixa temperatura envolvem o emprego de um filme metálico (selagem eutética) ou de silicato entre o substrato e a cobertura ${ }^{26}$. Os processos de selagem descritos são considerados irreversíveis, uma vez que a cobertura não é facilmente removida após o processo. No entanto, selagens reversíveis podem ser obtidas através do emprego de coberturas confeccionadas com polímeros elastoméricos como, por exemplo, o polidimetilsiloxano (PDMS) ${ }^{27}$. A vedação ocorre devido à formação de interações de van der Waals e, dessa forma, não resistem à aplicação de pressões superiores a $30 \mathrm{kPa}$.

\section{TECNOLOGIAS ALTERNATIVAS}

As tecnologias convencionais, propiciam a fabricação de microestruturas com excelente definição e resolução. No entanto, o custo de implementação de um laboratório é extremamente alto. Para a construção de um laboratório de microfabricação contendo ambiente completamente limpo, estação fotolitográfica, "spinner", chapas de aquecimento, perfilômetro, dentre outros, é necessário um investimento superior a um milhão de reais. Além disso, há a necessidade de material de consumo como fotorresistes, reveladores, máscaras metálicas, substratos de vidro, silício e quartzo, os quais também apresentam custo elevado. Estes fatores desencorajam muitos pesquisadores a se aventurarem nessa área. No Brasil, há um laboratório multi-usuários no qual toda a infra-estrutura necessária para a fabricação de microestruturas está disponível aos pesquisadores. O Laboratório de Microfabricação (LMF) está localizado no Laboratório Nacional de Luz Síncrotron (LNLS), vinculado ao Ministério de Ciência e Tecnologia/CNPq, localizado na cidade de Campinas/SP. Informações sobre o acesso a esta infra-estrutura podem ser encontradas em http://www.lnls.br.

Apesar dos processos convencionais serem os métodos mais utilizados na preparação dos $\mu \mathrm{TAS}$, a pesquisa por métodos alternativos e economicamente viáveis, é um permanente objetivo da comunidade científica. 


\section{Técnicas de microfabricação por moldagem}

Nas técnicas de microfabricação por moldagem, inicialmente um molde rígido é fabricado contendo a imagem negativa da estrutura microfluídica de interesse. Este molde é utilizado na etapa de replicação dos microdispositivos, a qual consiste em transferir a estrutura microfluídica do molde para o substrato, através de moldagem $^{28-30}$. Geralmente o substrato é um material polimérico, embora metais e cerâmicas também possam ser utilizados. São processos mais rápidos e de menor custo que as técnicas convencionais (fotolitográficas), o que os tornam adequados para produção de dispositivos microfluídicos em larga escala. A seguir, serão discutidas as etapas de fabricação do molde, de replicação e selagem dos microdispositivos.

\section{Fabricação dos moldes}

É a etapa que consome maior tempo e também representa o maior custo do processo. No entanto, o molde pode ser empregado diversas vezes na etapa de replicação dos dispositivos microfluídicos. O material empregado na fabricação dos moldes depende do processo de replicação empregado. O molde mais simples, relatado na literatura ${ }^{31}$, é aquele no qual se emprega um fio metálico com poucas dezenas de micrometros de diâmetro, para gerar microcanais sobre substratos poliméricos. No entanto, moldes com estruturas mais complexas são fabricados sobre substrato de silício ou vidro, empregando técnicas de fotolitografia com corrosão úmida ou seca do substrato ${ }^{32,33}$. Quando o processo de replicação não envolve altas pressões e temperaturas o molde pode ser confeccionado apenas com fotorresiste, sem necessidade de corrosão do substrato ${ }^{34}$. O fotorresiste SU-8 tem sido o mais empregado para esta finalidade, devido à sua elevada resistência química, possibilidade de deposição de filmes espessos e alta fotossensibilidade (menor tempo de exposição à radiação).

Outro processo de microfabricação bastante difundido envolvendo confecção de moldes é o LIGA ("Lithography, Galvo and Abformung"), sigla em alemão que significa litografia, eletroformação e moldagem. A Figura 4 apresenta as principais etapas do processo LIGA para obtenção do molde ${ }^{6}$.

Um filme de fotorresiste é depositado por "spin coating" sobre a superfície de um substrato. A seguir, uma etapa de fotolitografia é realizada, em que a estrutura do molde é transferida para o fotorresiste. A próxima etapa envolve o preenchimento dos microcanais formados com metal, geralmente níquel, através de deposição eletrolítica ou não eletrolítica. O molde é finalizado com a remoção do fotorresiste, formando uma microestrutura de metal em alto relevo. No início do desenvolvimento da técnica LIGA a etapa de fotolitografia era conduzida com raios-X provenientes de uma fonte de radiação síncrotron. A maior penetrabilidade e o paralelismo desta fonte de radiação garantem a obtenção de microestruturas com grande razão de aspecto (relação entre a altura e a largura do canal). No entanto, uma fonte de luz síncrotron representa um custo elevado e logo o processo foi adaptado para luz ultravioleta (LIGA-UV), com decorrente perda de resolução ${ }^{35}$.

\section{Replicação dos dispositivos microfluídicos a partir de moldes}

$\mathrm{O}$ processo de replicação dos microdispositivos a partir de um molde é genericamente representado na Figura 5. Os processos de replicação mais utilizados são a estampagem a frio, estampagem a quente, moldagem por injeção e litografia macia.

No processo de estampagem a frio o padrão microfluídico, preparado em um molde, é transferido para o substrato através de prensagem à temperatura ambiente, enquanto na estampagem a quente o processo é realizado sob aquecimento. Nestes processos, geralmente o
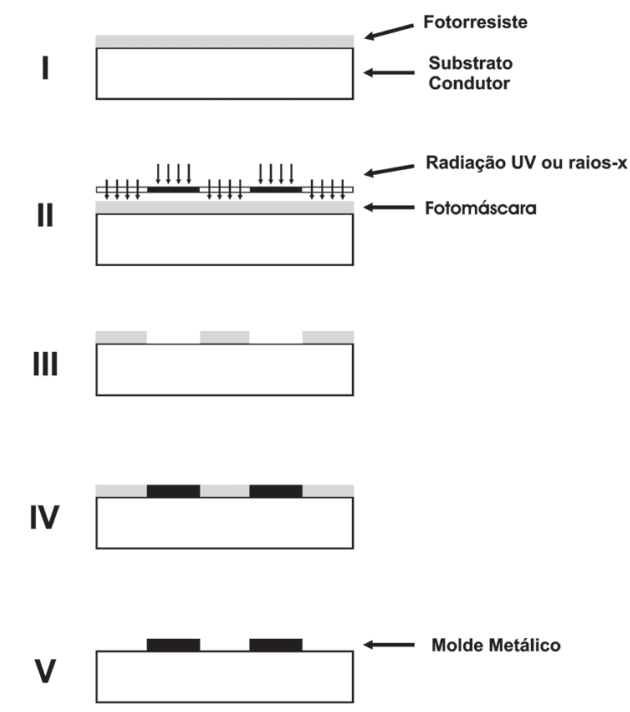

Figura 4. Principais etapas da construção de um molde envolvendo processo LIGA: (I) deposição de fotorresiste negativo sobre o substrato condutor ou com condutor depositado; (II) posicionamento da fotomáscara e exposição à radiação $U V$; (III) revelação da imagem fotogravada no fotorresiste; (IV) deposição de metal a partir de processo eletrolítico; (V) obtenção do molde metálico, após remoção do fotorresiste

substrato deve apresentar elevada dureza, o que exige grande resistência mecânica dos moldes. Por esse motivo, os moldes são comumente confeccionados em silício ou metal. Os dispositivos microfluídicos obtidos por estampagem a quente apresentam dimensões muito próximas às do molde de origem. Por outro lado, os obtidos por estampagem a frio dependem das características do substrato, da pressão aplicada e do tempo de prensagem ${ }^{28}$. No entanto, o tempo de produção de um microdispositivo por estampagem a frio é menor que o processo com aquecimento. Os moldes empregados em estampagem a quente apresentam tempo de vida maior devido à menor pressão utilizada, uma vez que o substrato é aquecido a uma temperatura próxima à de transição vítrea do material. Os substratos poliméricos mais empregados em estampagem a frio e a quente são o poli(metilmetacrilato) (PMMA), poliestireno (PE), poli(cloreto de vinila) (PVC), poli(etilenotereftalato) (PET) e policarbonato (PC). Equipamentos comerciais destinados a processos de estampagem a quente podem ser adquiridos ${ }^{29}$.

No processo de moldagem por injeção um polímero termoplástico é fundido e injetado (despejado) sobre o molde ${ }^{28}$. Como a viscosidade do polímero fundido é baixa, o mesmo acaba por recobrir integralmente o molde. Após o resfriamento, o conjunto molde/substrato é desmoldado e obtém-se o substrato com a estrutura microfluídica do molde (uma imagem negativa). Como a pressão envolvida na moldagem por injeção é menor que a empregada nos processos de estampagem, o molde não necessita ser confeccionado em metal. Moldes obtidos a partir de corrosão de silício ou por deposição de fotorresiste são adequados para este processo. PMMA e PC são os polímeros mais empregados no processo de microfabricação envolvendo moldagem por injeção.

No processo de litografia macia um polímero linear é misturado a um agente reticulador e colocado em contato com um molde. Após a reticulação, o polímero torna-se sólido e, de maneira análoga ao processo de moldagem por injeção, a estrutura microfluídica do molde é transferida para o polímero reticulado ${ }^{36,37}$. O PDMS é o material mais empregado neste processo, devido às excelentes propriedades ópticas, baixo custo, boa resistência química e alta flexibilidade ${ }^{27,34,38,39}$. No entanto, outros materiais, tais como a poliuretana 
elastomérica ${ }^{40}$, preparada a partir do óleo de mamona, e resinas epóxi ${ }^{41}$ também podem ser empregados na litografia macia. Por não envolverem altas pressões e temperaturas na etapa de replicação, os moldes não necessitam apresentar altas resistências mecânica e térmica, de modo que geralmente são confeccionados em silício ou fotorresiste reticulado.

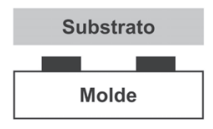

I

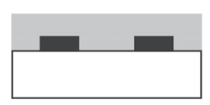

II

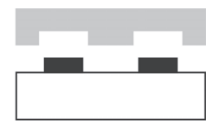

III
Figura 5. Processo de replicação de dispositivos microfluídicos a partir de um molde. (I) e (II) moldagem; (III) desmoldagem

Selagem dos microdispositivos fabricados por moldagem

Os microdispositivos obtidos por moldagem em substratos poliméricos são selados com maior facilidade que os microdispositivos fabricados sobre substratos de silício e vidro. Geralmente a cobertura e o substrato apresentam a mesma composição e as selagens são conduzidas a baixas temperaturas. Um dos métodos de selagem mais empregados é a térmica, na qual o substrato e a cobertura são pressionados e aquecidos em temperaturas próximas à de fusão ou transição vítrea dos materiais ${ }^{42}$. O aquecimento pode ser realizado direta ou indiretamente empregando-se ultrasom, laser, microondas ou radiofreqüência. A temperatura da selagem pode ser consideravelmente reduzida se uma camada de poliimida, resina epóxi, adesivo termoplástico ou camada de fotorresiste for colocada entre o substrato e a cobertura. Em alguns casos esta selagem pode ser realizada à temperatura ambiente, porém um cuidado especial deve ser adotado para evitar a obstrução dos canais com a camada adesiva. Outro método de selagem bastante difundido emprega polímeros elastoméricos, como o PDMS, para selagens reversíveis, na qual o polímero é utilizado como cobertura e adere ao substrato através de forças de van der Waals ${ }^{27}$. No entanto, também é possível realizar selagens irreversíveis com PDMS com uma prévia ativação da superfície deste polímero por plasma, de maneira que ocorram ligações covalentes entre substrato e PDMS ${ }^{34}$, ou ainda, manter contato direto com uma superfície durante o processo de cura do polímero.

\section{Ablação a laser}

Nesta técnica de microfabricação, um laser UV pulsado incide sobre a superfície de um substrato polimérico, causando fotodegradação e termodegradação do material ${ }^{28,29}$. As elevadas temperaturas locais atingidas geram ondas de choque, as quais causam pequenas explosões na superfície do polímero, de maneira que pequenas partículas e produtos gasosos $\left(\mathrm{CO}, \mathrm{CO}_{2}\right.$ etc.) são expelidos. Empregando-se uma máscara é possível transferir seu padrão microfluídico para o substrato. No entanto, a máscara pode ser eliminada realizando-se a escrita (ablação) diretamente sobre o substrato, através de um laser focalizado e um suporte para o substrato que permita uma movimentação precisa (programável) nos eixos $x-y$, permitindo o desenho da estrutura microfluídica. As fontes de laser mais empregadas são compostas de $\operatorname{ArF}(193 \mathrm{~nm})$ e $\mathrm{KrF}(248 \mathrm{~nm})$. A profundidade dos canais produzidos depende de parâmetros, tais como absorção de radiação pelo substrato, potência do laser, taxa de pulsação do laser e tempo de exposição. Os substratos poliméricos mais empregados são PMMA, PC, PVC, PET, PE, politetrafluoretileno e poliimida ${ }^{28,29,43}$. Como geralmente substratos poliméricos são empregados na microfabricação por ablação a laser, a selagem dos microdispositivos pode ser realizada através dos processos apresentados para a técnica de microfabricação por moldagem.

\section{Processo de impressão direta}

Outro processo alternativo e economicamente atrativo baseia-se no uso de toner para a fabricação de microdispositivos analíticos. A história do toner na microfabricação é curta, porém, altamente promissora. Tan e colaboradores ${ }^{44}$ inicialmente propuseram o uso de máquinas fotocopiadoras para gerar moldes descartáveis, os quais foram então empregados para a rápida prototipagem de microestruturas em PDMS. Do Lago e colaboradores ${ }^{45}$ propuseram um processo de impressão direta para a rápida produção de microdispositivos. Neste processo, os padrões de imagens são impressos sobre um filme de poliéster (transparência de retroprojeção) usando uma impressora laser para depositar seletivamente uma camada de toner, a qual define as dimensões dos canais microfluídicos. Após serem impressos, estes padrões são laminados contra uma folha de transparência limpa ou contra uma imagem especular do padrão, formando canais com simples ou dupla camada de toner, respectivamente. Os padrões de imagem (configuração dos microdispositivos) podem ser projetados em "softwares" como o Corel Draw ou AutoCad, sendo impressos na transparência através de uma impressora laser. A impressora produz a imagem enviada pelo computador através de uma série de pontos. Conseqüentemente, a resolução é geralmente expressa em "dpi” (“dots per inch" - pontos por polegada). Esta tecnologia brasileira resultou no processo mais simples, fácil e rápido, e de menor custo por dispositivo, entre todos os processos de microfabricação descritos na literatura, até o momento.

A tecnologia de impressão direta tem sido utilizada para confecção de microdispositivos para separações eletroforéticas ${ }^{45-49}$, para mistura de soluções ${ }^{50}$, microeletrodos em discos compactos (CDtrodos) $)^{46,51,52}$, celas microfluídicas com eletrodos interdigitados ${ }^{53}$, além de moldes descartáveis para a rápida prototipagem de microestruturas poliméricas ${ }^{54}$.

Os microdispositivos fabricados em poliéster-toner têm sido aplicados para rápidas separações eletroforéticas de ânions ${ }^{46}$ e cátions inorgânicos ${ }^{45,49}$, catecolaminas ${ }^{47}$ e fármacos ${ }^{48}$, utilizando detecção amperométrica (DA $)^{46-48}$ e detecção condutométrica sem contato $\left(C^{4} \mathrm{D}\right)^{45,49}$. Além dos métodos de detecção eletroquímicos, do Lago e colaboradores ${ }^{45}$ também mostraram que a fabricação de microchips para formação de "eletrospray" para espectrometria de massas é perfeitamente aplicável.

A tecnologia de impressão direta vem sendo utilizada para fabricação de microeletrodos de Au em discos compactos regraváveis (CDs) ${ }^{51}$. Neste caso, as máscaras são impressas em papel vegetal e posteriormente transferidas para a superfície do CD. As máscaras de toner delimitam a área dos eletrodos, enquanto a área não protegida é facilmente corroída com solução de $\mathrm{KI} / \mathrm{I}_{2}$. CDtrodos fabricados por este processo têm sido aplicados para DA em sistemas de CE convencional ${ }^{52}$ e em micro-escala ${ }^{46}$. A combinação das etapas de impressão direta e transferência térmica também foi usada por do Lago e colaboradores ${ }^{55,56}$ para a produção de microestruturas em vidro-toner.

\section{INSTRUMENTAÇÃO}

A simples confecção de canais utilizando as técnicas de microfabricação, já detalhadas, está longe de configurar um microssistema de análise. Após a etapa de fabricação dos canais, vários aspectos devem ser levados em consideração para o funcionamento do dispositivo. Como exemplos, podem-se citar as estratégias para a manipulação dos fluídos nos canais, para a injeção de amostra, detecção, dentre outras. De fato, um dos grandes desafios 
na construção de microssistemas de análises reside justamente na comunicação entre o ambiente microscópico e o mundo macroscópico, com o qual o analista está habituado e para o qual a maioria dos métodos de análises está estabelecida. É claro que algumas destas etapas podem ser implementadas no momento da confecção do dispositivo, como, por exemplo, a deposição (integração) de eletrodos para detecção eletroquímica no canal. Idealmente, todas as etapas analíticas e processos deveriam estar integradas no dispositivo, mas poucos exemplos de sistemas completos são encontrados na literatura no presente estágio de desenvolvimento.

A instrumentação necessária aos microssistemas de análises envolve, de maneira geral, um sistema responsável pelo bombeamento dos fluídos pelos canais e um detector estrategicamente posicionado. Dependendo do tipo de aplicação, outras operações podem ser incorporadas. Bons exemplos são os $\mu$ TAS para amplificação de DNA utilizando PCR ("polymerase chain reaction"), onde ciclos de aquecimento podem ser desenvolvidos através da passagem de corrente elétrica sobre filmes condutores depositados sobre os substratos durante o processo de microfabricação.

De acordo com a complexidade das conexões entre os canais, os esquemas de mobilização dos fluídos podem envolver diversas concepções e estratégias para o controle seletivo do fluxo, desde a introdução de válvulas integradas ${ }^{57,58}$, ou simplesmente usar uma bomba pneumática posicionada externamente para a mobilização dos fluídos ${ }^{59}$.

\section{Bombeamento}

A tecnologia de fabricação de micro-válvulas ou microssistemas eletromecânicos (MEMS) mais sofisticados pode ser empregada na integração de microbombas para a movimentação dos fluídos ${ }^{60}$. Basicamente, as microbombas integradas podem ser de dois tipos: dinâmicas (centrífuga, eletrodinâmica, eletrosmótica, magnetodinâmica, ultrassônica e outros efeitos especiais) ou de deslocamento (diafragma, pistão, rotatória, aperiódica). A Figura 6 mostra como uma bomba pode ser implementada a partir de duas válvulas e um elemento piezelétrico conectado a um diafragma. A diferença de potencial aplicada ao piezelétrico pode ser controlada para causar a sucção do fluído para dentro da câmara (Figura 6a). A inversão do potencial causa a expansão do piezelétrico e expulsa o fluído da câmara (Figura 6b). A referência 60 traz uma boa revisão dos principais tipos de microbombas e inclui explicações sobre os princípios de funcionamento. Uma variação desta estratégia vem sendo explorada através da integração de uma câmara difusora com uma membrana acoplada a um cristal piezelétrico ${ }^{61}$. Neste caso, o processo de fabricação é simplificado, pois dispensa a incorporação das válvulas.

Válvulas de membranas finas elastoméricas (por exemplo, de PDMS) podem ser posicionadas em série sobre o microcanal e acionadas seqüencialmente, provocando o deslocamento dos fluídos, de maneira semelhante a uma bomba peristáltica ${ }^{62}$. De maneira geral, a introdução destas microbombas de deslocamento aumenta significativamente o grau de complexidade dos dispositivos, o que

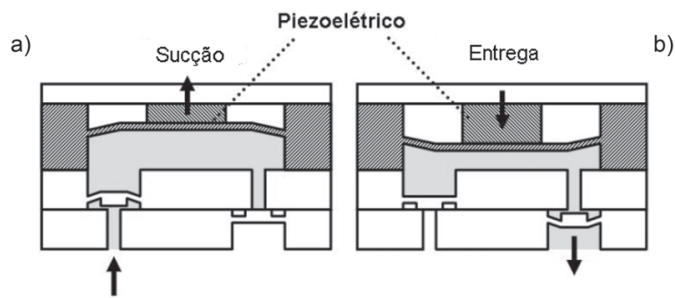

Figura 6. Microbomba de membrana integrada. Adaptada da ref. 60 pode requerer um controle cuidadoso dos processos de microfabricação.

Por não requerer etapas adicionais de microfabricação, o bombeamento através do fluxo eletrosmótico (EOF) é uma das formas mais empregadas de manipulação dos fluídos em microcanais. $\mathrm{O}$ EOF está relacionado à distribuição não uniforme de íons nas regiões próximas às paredes dos canais, quando estas possuem excesso de carga. A magnitude do EOF é dependente, portanto, do tipo do material utilizado como substrato e das propriedades da solução que preenche os canais $(\mathrm{pH}$, viscosidade, constante dielétrica e força iônica). Na prática, este tipo de mobilização do fluído favorece a aplicação do microssistema em separações eletroforéticas, como por exemplo, eletroforese de zona (CZE) ou isotacoforese (ITP), eletrocromatografia (CEC) etc., uma vez que a fonte de alta tensão já está disponível na integração da plataforma microfluídica. Este tipo de mobilização do fluxo é muito interessante, pois é possível selecionar facilmente os canais por onde o fluxo deve passar pela aplicação do potencial nos reservatórios correspondentes a esses canais (Figuras 7a e 7b). Caso a aplicação necessite de um fluxo livre do campo elétrico gerado na aplicação do potencial, pode-se ainda utilizar o EOF gerado em um ou mais canais auxiliares e acoplar este fluxo ao canal de interesse (Figura $7 \mathrm{c})^{63-66}$. Outras estratégias podem ser encontradas na literatura, como por exemplo, a exploração do fenômeno de eletrocapilaridade do mercúrio para criar um mecanismo de pistão em um capilar acoplado ao canal $^{67}$ ou o deslocamento do fluído pela geração de bolhas de maneira controlada em um microcanal ${ }^{68,69}$.

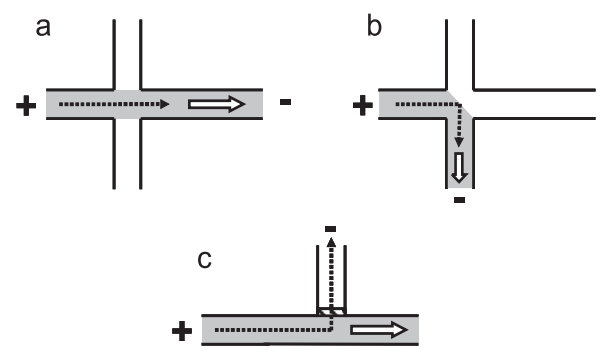

Figura 7. Bombeamento através do EOF. A direção do fluxo pode ser facilmente controlada através do chaveamento do potencial aplicado aos canais $(a)$ e (b); através de uma junção porosa é possível obter o fluxo livre da influência do campo elétrico aplicado para o bombeamento (c). Na representação assume-se que o EOF é catódico, ou seja, as paredes dos canais apresentam carga negativa

\section{Introdução da amostra}

O sistema de introdução da amostra é uma das etapas mais importantes do processamento analítico desenvolvido em dispositivos microfluídicos. Embora em sistemas convencionais a introdução da amostra seja realizada por ações eletrocinéticas e/ou hidrodinâmicas, em sistemas miniaturizados, devido à maior facilidade de implementação, esta etapa se faz predominantemente por processos eletrocinéticos $^{70,71}$. No entanto, alguns artigos relacionados à injeção hidrodinâmica em microchips podem ser encontrados na literatura ${ }^{57,72,73}$. A importância da introdução de amostra deve-se ao fato de que as características da zona de amostra determinam a qualidade da separação analítica. Além disso, para um estudo quantitativo há a necessidade de uma boa repetibilidade das injeções. O manuseio eletrocinético do fluído não requer componentes adicionais, além de eletrodos para aplicação de campo elétrico, eliminando, assim, a necessidade de acoplar microbombas e microválvulas. Devido à simplicidade instrumental, a eletroforese capilar (CE) é o principal método 
de separação desenvolvido em micro-escala. Com relação à injeção eletrocinética, há basicamente três métodos freqüentemente utilizados em microdispositivos. Estes métodos baseiam-se nos modos "unpinched"74, "pinched"75 e "gated"76.

No modo mais simples de injeção eletrocinética, "unpinched", a zona da amostra é determinada basicamente pela geometria dos microcanais que pode ser na forma de cruz, de um duplo-T, ou ainda, de um triplo-T. A diferença básica está no volume de amostra formado, determinado pela geometria dos microcanais. Para melhor compreensão, a Figura 8 apresenta o esquema do controle eletrocinético nos microcanais. Na Figura 8 é apresentado um esquema básico da configuração dos microcanais na geometria de uma cruz. Para realizar a injeção uma diferença de potencial é aplicada no canal de injeção durante 1-10 s, pelos eletrodos posicionados nos reservatórios da amostra (1) e de descarte da amostra (3) (Figura 8B). Neste curto período de tempo, a tendência é que o microcanal de injeção fique completamente preenchido com a amostra (Figura 8C). Após completar o preenchimento do microcanal de injeção, a etapa de separação é iniciada pela aplicação de uma diferença de potencial no canal de separação nos eletrodos posicionados nos reservatórios do tampão (2) e de descarte do tampão (4), também denominado de reservatório de detecção. Deste modo, a zona de amostra definida pela intersecção dos canais (volume de amostra injetada = volume da intersecção dos canais) é transportada na direção do detector (Figura 8D) e as espécies são separadas de acordo com suas mobilidades eletroforéticas ${ }^{74}$.
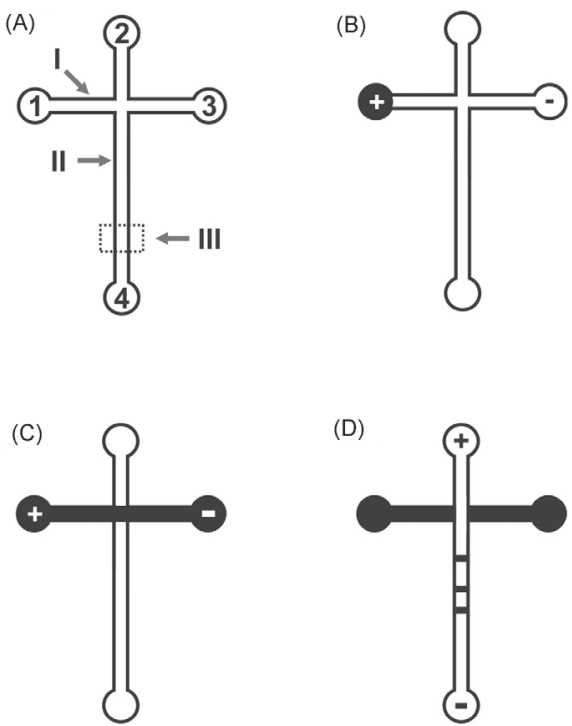

Figura 8. Esquema de controle eletrocinético nos microdispositivos. (A), Configuração dos microcanais. 1, 2, 3 e 4 representam os reservatórios para amostra, tampão, descarte da amostra e descarte do tampão, respectivamente. I, II e III representam o canal de injeção, o canal de separação e o ponto de detecção. (B), (C), ilustração do preenchimento do canal de injeção. (D), separação analítica dos analitos de acordo com sua mobilidade eletroforética

\section{Fontes de alta tensão}

Diversas aplicações de microssistemas de análises requerem a utilização de elevados campos elétricos, tanto para o simples bombeamento dos fluídos, injeção de amostra ou a separação eletroforética dos analitos. Tipicamente, duas ou três fontes capazes de fornecer até $4000 \mathrm{~V}$ são suficientes para a maioria das aplicações, mas é possível utilizar uma única fonte através do chaveamento manual dos pontos de aplicação do potencial. Segundo Jacobson e colaboradores ${ }^{77}$, a injeção eletrocinética de amostras nos microcanais pode ser efetuada utilizando-se apenas uma fonte e o chaveamento da alta tensão entre os reservatórios da amostra e do tampão. Neste caso, apenas três reservatórios foram suficientes para a implementação do microssistema.

Há disponíveis no mercado vários tipos de módulos miniaturizados para utilização nestes microssistemas ${ }^{78,79}$, incluindo módulos com múltiplas saídas que podem ser controlados por computador através de uma interface digital/analógica (D/A). Ainda, sistemas com múltiplas saídas podem ser facilmente construídos a partir de módulos miniaturizados individuais ${ }^{80}$.

\section{Métodos de detecção}

A redução dos sistemas de análise, com a conseqüente redução na quantidade de analito injetado, traz à luz uma nova realidade: como detectar as quantidades ínfimas de material? Como exemplo, se a detecção por absorção de luz no ultravioleta-visível (UVvis) for empregada em um microcanal de $50 \mu \mathrm{m}$ para a detecção de uma espécie com absortividade molar de $1000 \mathrm{~L} \mathrm{~mol}^{-1} \mathrm{~cm}^{-1}$ (que pode ser considerada alta), na concentração $100 \mu \mathrm{mol} \mathrm{L} \mathrm{L}^{-1}$, a absorbância medida será de apenas $5,0 \times 10^{-6}$. Obviamente, o caminho óptico neste caso limita a magnitude do sinal observado. Mas, indiretamente, a quantidade reduzida de material requer que estratégias que apresentem baixos limites de detecção sejam empregadas. Outro ponto a ser considerado é a possibilidade de integração do detector ao microssistema, uma vez que essa é a idéia central dos $\mu$ TAS. Não é raro encontrar na literatura propostas de microdispositivos de análise onde o detector ocupa um volume muito maior que a parte microfluídica (por ex., ref. 20).

Encontra-se uma grande variedade de estratégias de detecção aplicadas a $\mu \mathrm{TAS}$, sendo esta área foco de intensa atividade de pesquisa. Basicamente, as estratégias de detecção podem ser divididas em ópticas, eletroquímicas e acopladas ${ }^{3,4,6,81-84}$. Aqui serão abordadas as mais comumente empregadas, mas outras estratégias de detecção específicas, como, por exemplo, para contagem e classificação de células, medidas de viscosidade, osmolaridade, sensores de pressão e temperatura, entre outras, também podem ser encontradas na literatura ${ }^{6}$.

\section{Detecção óptica}

Estratégias de detecção baseadas na absorção de radiação na região do UV-Vis e fluorescência são muito encontradas nos métodos instrumentais de análise. Em particular, a fluorescência tem sido um dos métodos preferidos, principalmente quando a fonte de radiação de excitação é do tipo laser (LIF), devido aos baixos limites de detecção conseguidos com esta técnica. Técnicas modernas de microscopia confocal têm sido utilizadas com sucesso para detecção por fluorescência, por simplificarem significativamente a instrumentação e proporcionarem ótimos resultados. Há, inclusive disponível comercialmente, um instrumento para processamento paralelo de amostras de fragmentos de DNA e RNA, além de proteínas e células que opera com LIF e eletroforese ${ }^{85}$.

Devido ao reduzido caminho óptico, técnicas de absorção molecular encontram aplicações limitadas a amostras onde o analito está presente em concentrações relativamente altas. Uma estratégia que pode ser facilmente implementada em $\mu$ TAS é a construção de celas de reflexões múltiplas, através da introdução de camadas refletoras. Outro aspecto interessante é a possibilidade de integração de componentes do espectrofotômetro ou fluorímetro aos microssistemas. A utilização de diodos emissores de luz (LED) convencionais ou laser, além da recente introdução dos LED orgânicos (OLED), torna possível a integração direta da fonte de radiação com os canais com ampla faixa de opções de comprimentos de onda. Além disso, vários traba- 
lhos têm demonstrado a viabilidade de integração de guias de onda aos microdispositivos. Por outro lado, não há muitos exemplos de integração do elemento detector, como fotodiodos ou similares. Fibras ópticas também têm sido utilizadas no acoplamento do sistema de detecção óptico com os microcanais. Outras estratégias de detecção óptica têm sido aplicadas aos microssistemas de análise, como absorbância termo-óptica (lentes térmicas), ressonância plasmônica de superfície, quimiluminescência, infravermelho, Raman, índice de refração e emissão atômica ${ }^{4-6}$.

\section{Detecção eletroquímica}

Das técnicas de detecção conhecidas, a eletroquímica é a que possui maior potencial para integração aos microssistemas fluídicos e, portanto, a que mais se aproxima do conceito de $\mu$ TAS. Os sistemas eletroquímicos de detecção podem ser divididos em amperométricos, voltamétricos, potenciométricos e condutométricos ${ }^{86,87}$. Além destes, recentemente tem aumentado a aplicação da espectroscopia de impedância eletroquímica como estratégia de detecção. De maneira geral, os detectores eletroquímicos apresentam baixos limites de detecção e aplicação a uma grande variedade de analitos. A construção dos detectores eletroquímicos envolve o posicionamento de microeletrodos de trabalho e referência (em alguns casos podem ser também utilizados eletrodos auxiliares). Etapas adicionais de deposição dos eletrodos podem ser incorporadas ao processo de microfabricação, o que facilita a incorporação do detector e aumenta consideravelmente a reprodutibilidade do sistema. Outra vantagem associada a este tipo de detecção relaciona-se ao fato de que na maioria das técnicas a resposta do detector deve-se a reações (ou equilíbrios) na superfície do eletrodo, tornando o sistema de detecção independente do volume físico da célula de detecção (compare-se com a limitação do caminho óptico imposta nos detectores por absorção de radiação). A detecção amperométrica é uma das mais utilizadas, devido aos baixos limites de detecção conseguidos, à facilidade e custo de implementação e à boa seletividade ${ }^{86,87}$. Aplicações de detectores condutométricos, principalmente sem contato com acoplamento capacitivo $^{88,89}$, têm crescido nos últimos anos.

\section{Métodos acoplados}

Em princípio, qualquer estratégia de detecção pode ser utilizada em microssistemas. Além da pequena quantidade de material analisado, outra limitação refere-se às baixas vazões encontradas nos microssistemas, que faz com que fluxos auxiliares sejam necessários. O tamanho físico do detector é outro ponto de consideração: em muitos casos, o detector precisa ser dimensionado para que o acoplamento possa ser efetuado. Levando em conta estes aspectos, é impressionante que técnicas como espectrometria de massas (MS) e ressonância magnética nuclear (RMN) tenham sido utilizadas em microssistemas de análise ${ }^{4,5}$

Devido aos ótimos limites de detecção e à possibilidade de caracterização estrutural, a MS encontra também grande aceitação em microssistemas de análise. O acoplamento microchip-MS e as aplicações destes sistemas são áreas de intensa atividade de pesquisa. Recentemente foi lançado no mercado um microssistema especialmente útil na análise de proteínas e estudos proteômicos, onde as etapas de tratamento da amostra ocorrem em um microssistema polimérico complexo. Os analitos são eluídos cromatograficamente e inseridos em um espectrômetro de massas através da ionização por "electrospray" 90 . No caso da RMN, novas tecnologias de fabricação de micro-enrolamentos tornaram possível a detecção direta em microcanais ${ }^{91}$. Mas apesar da RMN ser uma ferramenta importante, capaz de fornecer informações estrutu- rais, os limites de detecção alcançados por esta técnica não permitem sua aplicação em microssistemas para a determinação de espécies em baixas concentrações.

\section{APLICAÇÕES}

Entre as possíveis aplicações da microfluídica podem-se citar todas aquelas executadas em sistemas convencionais: separação de biomoléculas como proteínas, peptídeos, seqüenciamento de DNA, ensaios enzimáticos, imunoensaios, aminoácidos, aminas biogênicas, entre outros. Além disso, a versatilidade inerente à construção dos microdispositivos permite a execução de experimentos baseados em imobilização de biomoléculas e análises integrando reações químicas em várias etapas ${ }^{92}$.

\section{Análise genômica (DNA)}

A primeira separação de DNA em um microdispositivo foi publicada por Effenhauser e colaboradores ${ }^{93}$, em 1994. Desde então, esse tipo de análise sofreu um desenvolvimento bastante rápido e se tornou uma das principais aplicações em sistemas microfluídicos ${ }^{94}$. Nos microchips, o efeito Joule desprezível durante a aplicação de altos campos elétri$\cos$ e a amostragem de volumes reduzidos e bem definidos resultam em análises de DNA mais eficientes quando comparadas àquelas executadas em eletroforese capilar convencional ou em gel. Assim, seqüenciamentos de DNA, bem como rápidas e eficientes separações de oligonucleotídeos, fragmentos de DNA e RNA, têm sido extensivamente realizadas nesses microssistemas ${ }^{95}$. A análise de DNA envolve várias etapas: classificação e separação de células, digestão de células e purificação do DNA, amplificação do DNA, separação eletroforética e detecção. Encontram-se na literatura vários sistemas microfluídicos que possibilitam realizar uma, várias ou todas as etapas de uma análise genética ${ }^{96}$.

\section{Classificação e separação de células}

É a primeira etapa da análise e pode ser considerada a preparação da amostra. Como as amostras biológicas são, na maioria das vezes, de matriz muito complexa, é crucial que as células que contêm o DNA de interesse sejam separadas do material biológico. Várias técnicas de separação e classificação de células têm sido desenvolvidas em microdispositivos, incluindo separação por ativação com fluorescência ou magnetismo, separação mecânica e separação através de aplicação de campo elétrico ${ }^{97}$.

Os trabalhos que envolvem separação mecânica de células em microfluídica são, na maioria dos casos, baseados em filtração. Wilding e colaboradores ${ }^{98}$ usaram um microdispositivo contendo uma série de filtros em formato de ponte, com $3 \mu \mathrm{m}$ de largura, para separar células de glóbulos brancos de todo o material biológico contido em amostras de sangue. Nesse sistema, através de bombeamentro hidrodinâmico dos fluídos, as células foram separadas e, em seguida, o DNA foi amplificado usando PCR na mesma plataforma.

A grande diversidade das propriedades físicas dos diferentes tipos de partículas biológicas pode ser usada para o desenvolvimento de separadores de células. Células de glóbulos brancos, por ex., são extremamente aderentes, enquanto que células de glóbulos vermelhos são muito pouco aderentes. Valendo-se dessa diferença de propriedades, Carlson e colaboradore ${ }^{99}$ usaram força hidrodinâmica para bombear amostras de sangue através de microcanais empacotados com fase porosa para separar células de glóbulos vermelhos de células de glóbulos brancos. Enquanto as células de glóbulos vermelhos rapidamente penetravam e passavam pelos microcanais, o retardamento, e eventualmente a aderência, das células de glóbulos brancos 
permitiram a separação. Além disso, o sistema também possibilitou o fracionamento de diferentes tipos de células de glóbulos brancos.

Entre os diferentes tipos de separadores de célula, aqueles baseados em aplicação de campo elétrico são os mais convenientes para sistemas miniaturizados devido, principalmente, à relativa facilidade de gerar e estruturar o campo elétrico no microdispositivo ${ }^{97}$. Como a maior parte das células possui mobilidades eletroforéticas semelhantes, o emprego da eletroforese para separação de células é bastante limitado. Entretanto, a dieletroforese (DEP) tem sido empregada com sucesso na separação de vários tipos de células.

DEP é definida como um movimento lateral concedido a partículas não carregadas, como resultado da polarização induzida por campos elétricos não uniformes. Utilizando as interações entre as propriedades dielétricas intrínsecas das células e o campo AC aplicado, DEP tem sido bastante usada como ferramenta de separação de células. Usando DEP, uma grande variedade de células, incluindo bactérias, células cancerosas, células tronco e subpopulações de leucócitos, foram separadas. Huang e colaboradores ${ }^{100}$ demonstraram um microchip para DEP, com microcanais construídos em acrílico, para separar diferentes simuladores de agentes de guerra biológica denominados B. cereus, E. coli e L. monocytognens contidos em amostras de sangue. Cui e colaboradores ${ }^{101}$ desenvolveram dispositivos dieletroforéticos construídos em fotorresiste SU8 formados por multicamadas, como guias para separação de diferentes tipos de células.

\section{Digestão de células e purificação do DNA}

Após a separação das células de interesse, por meio de uma das técnicas mencionadas anteriormente, sua digestão é a próxima etapa da análise total. Vários grupos têm apresentado dispositivos microfluídicos, principalmente fabricados em materiais poliméricos, com propósito da digestão celular através de agentes químicos ${ }^{102-104}$, força mecânica ${ }^{105}$ ou pulsos elétricos ${ }^{106,107}$.

Métodos químicos são bastante comuns para digerir células. Como a membrana celular consiste em uma dupla camada lipídica, eletrólitos contendo surfactantes podem facilmente rompê-las. Vários microdispositivos foram desenvolvidos para a digestão química celular. Irimia e colaboradores ${ }^{103}$ construíram um microdispositivo em PDMS que integrava a captura e a digestão de uma única célula em um volume de $50 \mathrm{pL}$. Nesse trabalho, a digestão celular foi realizada com o uso de dodecil sulfato de sódio (SDS). Carlo e colaboradores ${ }^{104}$ apresentaram um novo microdispositivo construído em PDMS para a digestão celular com íons hidróxido eletro-gerados in situ. Três diferentes tipos de células foram eficientemente digeridas usando esse método.

Um segundo método bastante comum empregado na digestão de células é a "lise" mecânica. Taylor e colaboradores ${ }^{105}$ desenvolveram um minissonicador construído em conjunção com um microdispositivo para PCR. Células provenientes de diferentes bacilos foram digeridas no minissonicador em menos de $30 \mathrm{~s}$ e, em seguida, o DNA proveniente das mesmas passou para a etapa de amplificação.

A aplicação de pulsos elétricos para a digestão celular é conhecida também como eletroporação ${ }^{106,107}$. Lu e colaboradores ${ }^{106}$ desenvolveram um microdispositivo em SU-8 para digestão celular por eletroporação. Nesse sistema, com a aplicação de campos elétricos de $1 \mathrm{kV} / \mathrm{cm}$ e um potencial AC de $10 \mathrm{~V}$, células cancerígenas foram digeridas com o material genético pronto para análise subseqüente.

O isolamento do DNA altamente purificado é muito importante para a maioria das aplicações biotecnológicas subseqüentes, sobretudo no que diz respeito ao desenvolvimento de novas aplicações terapêuticas. Dessa maneira, o desenvolvimento de métodos efetivos para a extração e purificação de DNA é bastante explorado na microfluídica. A maior parte dos procedimentos usados para ex- tração de DNA depende da utilização de lisozima ou outras enzimas lipofílicas ou proteolíticas. Entretanto, várias bactérias são resistentes à ação da lisozima e, portanto, outros protocolos são necessários. A extração de DNA tem sido feita eficientemente com o uso de um sistema tampão e extração em fase sólida ${ }^{108}$. A extração de DNA usando fases sólidas é baseada em interações iônicas entre o DNA e elementos catiônicos imobilizados ou não. Chung e colaboradores ${ }^{109}$ construíram um microchip em PMMA com fase sólida imobilizada para uma extração eficiente de DNA em células digeridas de E. coli. Quando o número de células usadas na extração foi de $10^{3}$ a $10^{4}$ em $25 \mu \mathrm{L}$ de amostra, a eficiência da extração foi bem maior (100 a 1000 vezes) no microchip quando comparada a outros métodos que usam fases sólidas não imobilizadas.

\section{Amplificação do DNA}

Atualmente, o método usado para amplificação de DNA é a PCR, que é uma metodologia in vitro que possibilita a reprodução de milhares de cópias de um determinado fragmento de DNA. Através desta técnica, uma seqüência particular de interesse pode ser amplificada, tornando-se majoritária na amostra de DNA. Deste modo, dois pequenos fragmentos de DNA, normalmente de 20 pares de bases ("primers"), são sintetizados in vitro. Estes primers são complementares às extremidades da região de DNA que se pretende amplificar ${ }^{110}$.

A PCR é realizada através de vários ciclos que possuem três estágios de temperatura cada: desnaturação das duas fitas das moléculas de DNA a $95{ }^{\circ} \mathrm{C}$; hibridização dos "primers" às regiões complementares das moléculas de DNA que estão separadas a $55^{\circ} \mathrm{C}$ e, extensão de um novo DNA, começando pelas regiões em dupla fita, local onde cada um dos "primers" se ligou ao molde da amostra de DNA a $72{ }^{\circ} \mathrm{C}$. Após isso, um novo ciclo é iniciado com a temperatura elevada a $95{ }^{\circ} \mathrm{C}$ novamente. Ao final de 30-35 ciclos de amplificação existe, tipicamente, 1 milhão de cópias do segmento de DNA de interesse para cada molécula molde original da amostra inicial $^{110}$

Vários microdispositivos têm sido construídos para aplicação em amplificação de DNA através da PCR ${ }^{94-96}$. Roper e colaboradores ${ }^{110}$ publicaram recentemente um trabalho de revisão que apresenta os avanços nessa área. Existem duas maneiras de executar a PCR em microchips. A mais comum delas é dependente do tempo requerido para atingir as diferentes temperaturas do ciclo. Ou seja, a mistura que contém os componentes da PCR é mantida em estado estacionário, enquanto a câmara de reação atinge as temperaturas requeridas. Esse método requer uma otimização bastante cuidadosa da taxa de transferência de calor para o sistema ${ }^{111}$. A segunda maneira é realizada em sistemas de fluxo contínuo, nos quais as temperaturas requeridas para o ciclo foram fixadas nas várias regiões do microdispositivo ${ }^{112}$.

Legendre e colaboradores ${ }^{111}$ desenvolveram um microdispositivo que integra as etapas de extração em fase sólida (SPE) e PCR na análise de DNA. O processo de SPE foi realizado usando partículas de sílica híbrida na fase sol-gel e a PCR em uma câmara de reação de apenas 1,6 $\mu \mathrm{L}$ aquecida através da radiação infravermelha. $\mathrm{O}$ microdispositivo, fabricado em vidro através da técnica fotolitográfica, permitiu a purificação e PCR de amostras contendo DNA de interesse em um tempo total de análise de $25 \mathrm{~min}$. A Figura 9 apresenta o desenho do microdispositivo, bem como as representações. Todos os microcanais foram construídos com $200 \mu \mathrm{m}$ de profundidade. O DNA purificado no canal da SPE, com 1,0 cm de comprimento e $140 \mu \mathrm{m}$ de largura, foi eluído para a câmara de PCR juntamente com os reagentes adicionados para PCR adicionados através de um microcanal de 2,25 $\mathrm{cm}$ de comprimento e $20 \mu \mathrm{m}$ de largura. As restrições representadas no desenho foram construídas para restringir o fluxo no canal de adição 
dos reagentes e reter a fase sólida no canal da SPE. A eluição do DNA na fase sólida extratora, bem como a adição dos reagentes necessários para a PCR, foram feitas utilizando uma bomba seringa. O sistema de infravermelho permitiu desenvolver os ciclos de aquecimento e resfriamento para a PCR com taxa de $10{ }^{\circ} \mathrm{C} / \mathrm{s}$. Essa taxa é 10 vezes mais rápida para aquecimento e 3 vezes mais rápida para resfriamento, quando comparada aos termo-cicladores convencionais.
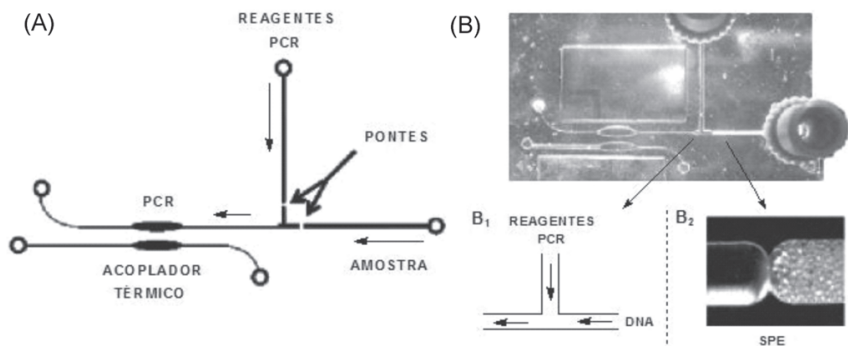

Figura 9. Microdispositivo usado para análises genéticas acoplando purificação e PCR de DNA. (A) Mostra os componentes do microssistema: entrada da amostra e reagentes, pontes restritoras de fluxo e da fase sólida da SPE, câmara de reação da PCR e acoplador térmico. (B) Fotografia do microdispositivo construído em vidro; $\left(B_{1}\right)$ movimento dos fluídos na intersecção dos microcanais $e\left(B_{2}\right)$ fase sólida da SPE. Reproduzido da ref. 111, com permissão da American Chemical Society

\section{Separação de DNA}

O uso da eletroforese para análise de DNA, também conhecida como análise genética, pode ser dividido em categorias mais comuns: seqüenciamento de DNA e genotipagem. Qualquer que seja o caso, a separação é feita por tamanho.

O seqüenciamento de DNA é uma análise que permite determinar a ordem das bases nitrogenadas (ou nucleotídeos) adenina, guanina, timina e citosina, em um fragmento de DNA. Isso pode ser feito através da marcação de cada nucleotídeo com um marcador fluorescente ou radioativo diferente. As análises de genotipagem fundamentam caracterizar diferenças genéticas entre genomas individuais. Essas diferenças são usadas para analisar herança de genes, identificar pessoas que possuem variantes de genes (alelos) que predizem doenças e claramente identificar diferentes pessoas em aplicações forenses.

Emrich e colaboradores ${ }^{113}$ demonstraram todo o potencial da microfluídica em análises genéticas simultâneas no desenvolvimento de um microdispositivo com arranjo de microcanais para análise simultânea de 384 amostras. Após amplificação usando PCR e digestão enzimática, o DNA de 384 indivíduos foi seqüenciado usando um único microdispositivo. O sistema (Figura 10A), de $200 \mathrm{~mm}$ de diâmetro, é constituído por quatro quadrantes com 24 quartetos de microcanais distribuídos radialmente em volta de um reservatório central anódico comum. Cada quarteto (Figura 10B) consiste em quatro microcanais com reservatórios de amostras individuais e interligados a um reservatório catódico em comum. As distâncias entre cada reservatório de amostra e o respectivo reservatório catódico comum são idênticas (Figura 10C). Os reservatórios possuem 1,5 mm de diâmetro e a distância entre eles é de 1,2 mm. Cada amostra é adicionada no respectivo reservatório, seqüenciada no microcanal (60 $\mu \mathrm{m}$ de largura, $30 \mu \mathrm{m}$ de profundidade e $8 \mathrm{~cm}$ de comprimento) preenchido com poli(di)metilacrilamida (PDMA) e detectada com um sistema confocal de fluorescência induzida a laser. A aplicabilidade desse bioanalisador foi demonstrada na genotipagem de uma mutação comum do gene humano HFE em 384 indivíduos em apenas $325 \mathrm{~s}$.

\section{Sistemas integrados}

A integração das várias etapas da análise de DNA em um único

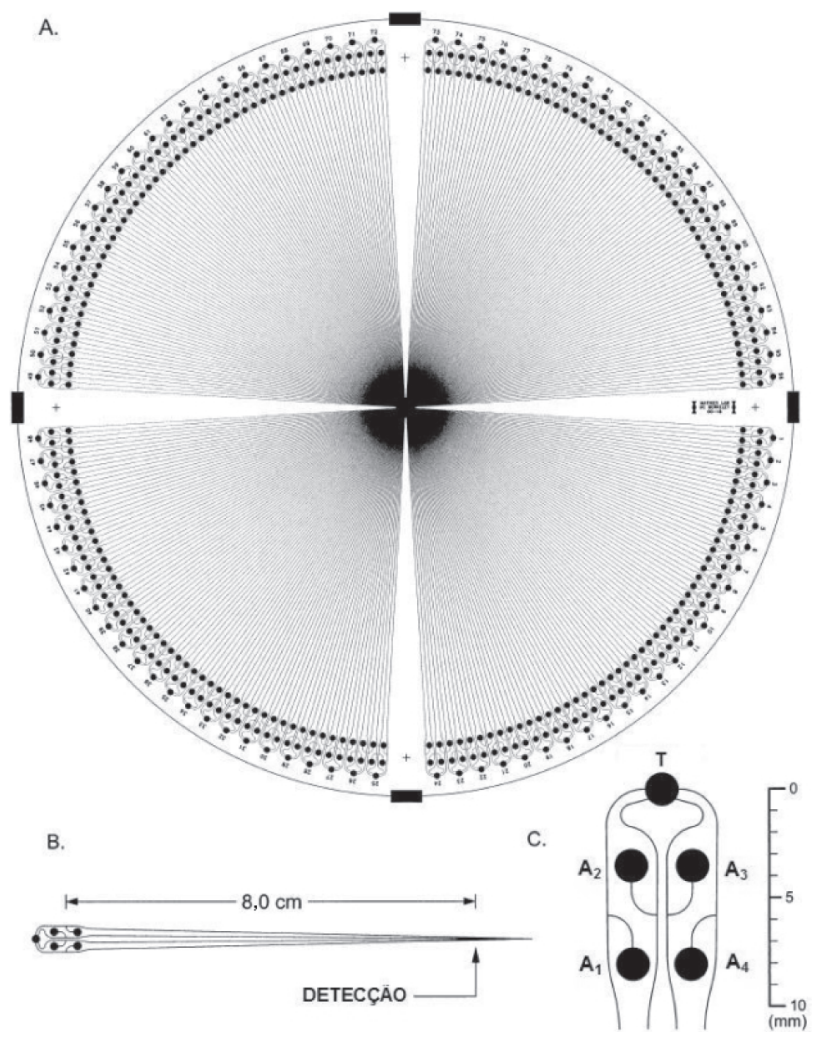

Figura 10. (A) Microdispositivo (200 mm de diâmetro) com 384 microcanais para análises genéticas simultâneas. Microcanais com $60 \mu \mathrm{m}$ de largura, 30 $\mu \mathrm{m}$ de profundidade e $8 \mathrm{~cm}$ de comprimento. (B) Desenho expandido de apenas um microcanal mostrando reservatórios e ponto de detecção. (C) Reservatórios para tampão de corrida $(T)$ e amostras $\left(A_{1}\right.$ a $\left.A_{4}\right)$ em cada microcanal. Reproduzido da ref. 113, com permissão da American Chemical Society

microdispositivo tem sido objeto de estudo de vários grupos de pesquisa $^{114-116}$. Nesse ponto, vários trabalhos poderiam ser citados mas nos limitaremos a apenas dois, que são de grande destaque. Ferrance e colaboradores ${ }^{114}$, além do trabalho discutido anteriormente de integração das etapas de purificação e PCR na análise DNA $^{111}$, também desenvolveram um microdispositivo que integra as etapas de PCR e separação dos fragmentos de DNA. O microdispositivo fabricado em vidro foi aplicado para diagnóstico de mutação genética em pacientes com distrofia muscular de Duchenne. Após purificadas em outro microdispositivo de SPE, as amostras contendo o DNA de interesse foram introduzidas na câmara de PCR de apenas $630 \mathrm{~nL}$ e, em seguida, separadas em um microcanal (50 $\mu \mathrm{m}$ de profundidade) e detectadas por LIF.

Um microdispositivo fabricado em PC que integra todas as etapas de uma análise de DNA foi desenvolvido por Liu e colaboradores ${ }^{116}$, do laboratório de microfluídica da Motorola. A preparação da amostra, incluindo captura magnética, pré-concentração, purificação e digestão de células, PCR, separação e detecção de DNA, foi executada em uma única plataforma. O bombeamento dos fluídos nos microcanais foi feito através do uso de microbombas termopneumáticas e, para regular o fluxo, microválvulas termicamente acionadas, construídas em parafina, foram acopladas ao sistema. Aplicações desse sistema foram demonstradas para detecção de polimorfismo de nucleotídeos individuais diretamente de amostras de sangue.

\section{Análise proteômica (proteínas e peptídeos)}

O método mais usado atualmente para analisar proteínas inclui 
sua extração da célula, separação por eletroforese em gel (uni ou bidimensional), digestão das proteínas separadas e análise dos peptídeos resultantes por espectrometria de massas (MS). Essa tradicional metodologia, embora bastante útil e poderosa, exige muito tempo e trabalho laboratorial. Nesse contexto, os microdispositivos oferecem novas oportunidades que não existem nas técnicas tradicionais de análise proteômica: rapidez, análise simultânea de amostras e potencial para controle e automação das várias etapas da análise ${ }^{117}$.

A maior parte dos desenvolvimentos recentes em microfluídica aplicada à análise proteômica está voltada para a combinação, em um único microdispositivo, da separação por eletroforese uni ou multi-dimensional e detecção por MS. Uma vez que a espectrometria de massas é a técnica mais usada para análise e caracterização de proteínas, vários trabalhos voltados ao acoplamento de microdispositivos com MS têm sido relata$\operatorname{dos}^{26}$. Como o acoplamento microchip-MS já foi abordado anteriormente, os exemplos de aplicação que apresentaremos a seguir serão mais voltados para eletroforese bidimensional (2D) em microdispositivos.

Os primeiros trabalhos envolvendo a análise de proteínas ou peptídeos em microdispositivos usando a eletroforese $2 \mathrm{D}$ foram $\mathrm{pu}-$ blicados por Ramsey e colaboradores ${ }^{118,119}$. Ambos os trabalhos integraram a cromatografia eletrocinética micelar (MEKC) e eletroforese capilar em zona (CZE), respectivamente, como primeira e segunda dimensão da eletroforese em 2D. Amostras de digeridos protéicos (peptídeos) foram separadas em ambos os sistemas.

$\mathrm{O}$ trabalho mais recente envolvendo o uso de eletroforese $2 \mathrm{D} \mathrm{em}$ microdispositivos para separação de proteínas foi publicado por Shadpour e Soper ${ }^{120}$. Eletroforese capilar em gel usando dodecil sulfato de sódio (SDS $\mu$-CGE) e MEKC foram usadas como modos de separação para eletroforese em microcanais para a primeira e para a segunda dimensão, respectivamente. O microdispositivo (Figura 11A) foi construído em PMMA usando a técnica de estampagem a quente, com microcanais de $20 \mu \mathrm{m}$ de largura e $50 \mu \mathrm{m}$ de profundidade. Como pode ser observada, a separação por SDS $\mu$-CGE foi executada na primeira dimensão em um microcanal de $30 \mathrm{~mm}$ e a separação por MEKC em um microcanal de $10 \mathrm{~mm}$ na segunda dimensão. A separação por SDS $\mu$-CGE ocorre pela diferença de tamanho das proteínas, que possuem mobilidades diferentes através dos poros do gel, enquanto que a separação por MEKC ocorre pela diferença de interação entre as proteínas e o surfactante SDS presente no tampão de corrida em concentração acima da micelar crítica.

A operação do microdispositivo é bastante interessante, primeiramente os microcanais e reservatórios são preenchidos com as respectivas soluções: (A) amostra; (B) descarte amostra; (C) tampão para SDS $\mu$-CGE; (D) descarte da SDS $\mu$-CGE; (E) tampão para MEKC e (F) descarte da MEKC. Através da aplicação de um potencial entre os reservatórios (A) e (B), a amostra (uma mistura de 10 proteínas) foi introduzida no canal de separação da SDS $\mu$-CGE e separadas por tamanho através da aplicação do campo entre os reservatórios (C) e (D). Os fluídos resultantes da separação por SDS mCGE foram repetidamente introduzidos, em intervalos de $0,5 \mathrm{~s}$ (chamados pelos autores de ciclos), no microcanal da MEKC aplicandose potenciais entre os reservatórios $(E)$ e $(F)$. A detecção através de LIF em dois pontos do microdispositivo, $\mathrm{d}_{1}$ e $\mathrm{d}_{2}$, monitorou as separações por SDS $\mu$-CGE e CGE, respectivamente. A Figura 11B apresenta um gráfico tridimensional resultante da análise das proteínas mostrando o número de ciclos (separação por SDS $\mu$-CGE) versus o tempo de migração da MEKC. O tempo total de corrida para MEKC de cada ciclo foi de $10 \mathrm{~s}$ e o tempo total da eletroforese em $2 \mathrm{D}$ foi de aproximadamente $12 \mathrm{~min}$, com uma capacidade total de 1000 picos.

Outros trabalhos envolvendo a análise de proteínas ou peptídeos em microdispositivos usando a eletroforese $2 \mathrm{D}$ foram realizados integrando focalização isoelétrica capilar (CIEF) com CZE ${ }^{121}$ e SDSCGE com $\mathrm{CIEF}^{122}$
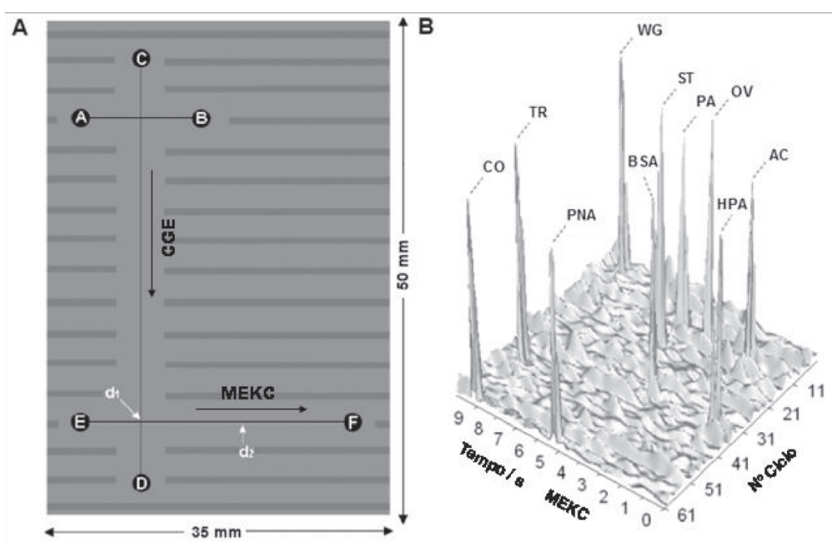

Figura 11. (A) Microdispositivo usado para eletroforese $2 D$ de proteínas. $O$ microdispositivo foi construído usando estampagem a quente com microcanais de $20 \mu \mathrm{m}$ de largura e $50 \mu \mathrm{m}$ de profundidade. Representações: $d_{1}$ ed $d_{2}$, pontos de detecção LIF; (A) amostra; (B) descarte amostra; $(C)$ tampão para SDS $\mu$-CGE; (D) descarte da SDS $\mu$-CGE; (E) tampão para MEKC e (F) descarte da MEKC. (B) Gráfico em 3D da análise mostrando o número de ciclos versus o tempo de migração da MEKC. Conjunto de proteínas: aglutinina (WG, $38 \mathrm{kDa}$ ), actina (AC, $43 \mathrm{kDa}$ ), ovalbumina (OV, $45 \mathrm{kDa}$ ), proteína $A(P A, 45 \mathrm{kDa})$, estreptavidina $(S T, 53 \mathrm{kDa})$, albumina sérica bovina (BSA, 66 kDa), lectina helix pomatia (HPL, $70 \mathrm{kDa})$, transferrina $(T R, 80$ $k D a)$, concanavalina A (CO, 104 kDa) e lectina-aglutinina de amendoim (PNA, 110 kDa). Reproduzido da ref. 120, com permissão da American Chemical Society

\section{Ensaios enzimáticos}

Enzimas podem converter em produtos, de maneira específica, $10^{2}-10^{5}$ moléculas de um substrato em um intervalo de tempo bastante pequeno. As propriedades catalíticas e seletivas têm conferido às enzimas uma ampla utilização em Química Analítica. Os ensaios enzimáticos são usados principalmente para dois propósitos distintos: determinar a atividade de uma enzima ou quantificar compostos que são substratos ou inibidores de uma reação enzimática ${ }^{123}$.

Em microfluídica, os ensaios enzimáticos são mais freqüentemente usados para derivação de analitos. Ou seja, uma espécie não detectável é convertida em uma espécie detectável após sofrer uma reação enzimática. Embora os primeiros experimentos de derivação/separação em microdispositivos tenham sido conduzidos com uso de reações químicas, o uso de reações enzimáticas também foi desenvolvido nesses sistemas, o que possibilitou a expansão do alcance e seletividade nas análises de diversas classes de compostos de interesse analítico ${ }^{124}$.

O desempenho de um ensaio enzimático "on-chip" depende do equilíbrio apropriado entre as condições de ocorrência da reação enzimática, da separação eletroforética e da detecção. $\mathrm{O}$ pH apropriado para ocorrência da reação enzimática pode, por exemplo, não ser o mais favorável para uma separação eficiente dos produtos. Assim, as condições devem ser ajustadas para que exista o melhor intercâmbio possível entre a alta taxa de conversão enzimática e a eficiência de separação ${ }^{125}$.

Existem várias maneiras de conduzir um ensaio enzimático usando eletroforese em microdispositivos. Os protocolos bioanalíticos podem ser primeiramente diferenciados pelo uso de enzimas solubilizadas ou imobilizadas. Devido à versatilidade e principalmente ao consumo reduzido de reagentes, os ensaios enzimáticos em microdispositivos têm sido conduzidos preferencialmente com o uso de enzimas solubilizadas. Nesse sentido, a reação enzimática pode ocorrer antes, durante ou depois da separação eletroforética ${ }^{124}$. 
Em todos os sistemas podem ser introduzidos misturadores para que a reação enzimática seja mais eficiente. No módulo em que a reação enzimática ocorre durante a separação eletroforética, a mesma ocorre no canal de separação de um microdispositivo convencional em cruz com a enzima presente no próprio eletrólito de corrida $^{125}$. Nos módulos em que a reação ocorre antes ou depois da separação eletroforética, microcanais adicionais são fabricados em junção com os microcanais do microdispositivo convencional.

Os primeiros trabalhos envolvendo ensaios enzimáticos "onchip" foram realizados por Ramsey e colaboradores ${ }^{125,126}$. Nesses ensaios foram feitos estudos de inibição da atividade das enzimas $\beta$-galactosidase $(\beta-G a l)^{125}$ e AchE ${ }^{126}$ em microdispositivos construídos em vidro. Concentrações precisas de substrato, enzima e inibidor foram misturadas, em volumes da ordem de nanolitros, usando controle eletrocinético dos fluídos. Em ambos os sistemas, realizou-se a determinação das constantes de Michaelis-Menten bem como a análise química dos inibidores.

Wang e colaboradores ${ }^{127}$ publicaram recentemente um trabalho, no qual um microdispositivo foi usado na determinação simultânea de glicose e insulina através da integração de ensaios enzimático e imunológico. A determinação simultânea de insulina e glicose e, conseqüentemente, a proporção insulina/glicose, é bastante relevante para o controle de diabetes e hipoglicemia. Como pode ser observado na Figura 12, o bio-ensaio foi realizado em um microdispositivo com reações químicas ocorrendo antes ("precolumn”) e depois ("post-column”) da separação eletroforética.

A operação do microdispositivo inicia-se com duas reações précoluna: insulina (antígeno) com a anti-insulina (anticorpo) derivada com a enzima fosfatase alcalina e glicose (substrato) com glicose desidrogenase (enzima) na presença do cofator NAD ${ }^{+}$. Essas reações pré-coluna são seguidas da separação eletroforética do anticorpo livre, do complexo insulina-anticorpo e do NADH formado na reação enzimática. Após separação, em uma reação pós-coluna, a anti-insulina livre derivatizada com a enzima fosfatase alcalina recebe o reagente $p$-nitrofenil fosfato ( $p$-NPP), formando o produto detectável $p$-aminofenol. Os produtos finais das reações “on-chip", NADH e $p$ aminofenol, foram monitorados amperometricamente usando como eletrodo de trabalho (ET), eletrodos de carbono "screen-printed". Finalmente, as concentrações quantificadas de NADH e $p$-aminofenol foram usadas para determinar as concentrações de glicose e insulina, respectivamente.

\section{Análise de pequenas moléculas}

Além das aplicações apresentadas anteriormente em análises genéticas, proteômicas e ensaios enzimáticos, a análise de moléculas pequenas como catecolaminas, aminoácidos, carboidratos, fenóis, fármacos em geral, pesticidas, enantiômeros, cátions, ânions, entre outros, tem sido extensivamente estudada usando eletroforese em microdispositivos construídos no formato convencional em cruz. Vários artigos de revisão podem ser encontrados na literatura ${ }^{92,123,128-130}$ e, a seguir, discutiremos somente alguns exemplos.

Uma das classes de compostos mais estudadas em separações eletroforéticas em microdispositivos são as catecolaminas. Essa classe de compostos desempenha um papel fundamental no sistema nervoso central atuando como neurotransmissores. Trabalhos que têm como objetivo apresentar novas técnicas de microfabricação ou sistemas de detecção geralmente apresentam separações de catecolaminas como compostos modelos ${ }^{131-133}$. A determinação simultânea de dopamina, norepinefrina, L-DOPA, DOPAC e ácido ascórbico em amostras de plasma, foi realizada por Johirul e colaboradores ${ }^{134}$ usando eletroforese de zona em microdispositivos construídos em vidro. Com detecção amperométrica utilizando ele-

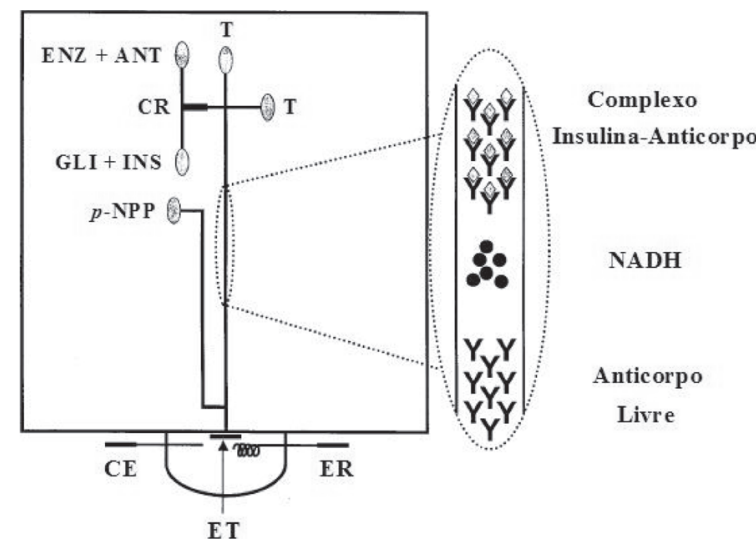

Figura 12. Microdispositivo usado para determinação simultânea de glicose e insulina através de ensaios enzimático e imunológico. (T) tampão de corrida, (ENZ) enzima glicose desidrogenase, (ANT) anti-insulina marcada com fosfatase alcalina, (GLI) glicose, (INS) insulina, (CR) câmara de reação, ( $p$ $N P P)$ p-nitrofenil fosfato, (ET) eletrodo de trabalho, (CE) contra eletrodo $e$ (RE) eletrodo de referência. Reproduzido da ref. 127, com permissão da American Chemical Society

trodos de carbono modificados com celulose-DNA, limites de detecção em torno de $1 \mu \mathrm{mol} \mathrm{L} \mathrm{L}^{-1}$ foram obtidos nesse trabalho.

Aminoácidos constituem outra classe de compostos de grande relevância em bioquímica que também tem sido foco de extensa aplicação da eletroforese em microdispositivos. Vários trabalhos têm sido desenvolvidos, sempre mostrando as potencialidades dos diferentes modos de separação e detecção ${ }^{135-139}$. Munro e colaboradores ${ }^{135}$ apresentaram uma eficiente separação de vários aminoácidos, incluindo lisina, prolina, leucina, histidina, treonina, alanina, serina, glicina e tirosina, em menos de $90 \mathrm{~s}$, usando eletroforese de zona em microdispositivos de vidro. O modo de detecção usado foi LIF indireto, obtendo limites de detecção em torno de $30 \mu \mathrm{mol} \mathrm{L}{ }^{-1}$. Outro exemplo da aplicação de microdispositivos na análise de amino ácidos foi publicado por Throckmorton e colaboradores ${ }^{136}$ usando eletrocromatografia como modo eletroforético de separação. Separações mais eficientes e bem mais rápidas, quando comparadas à $\mathrm{CE}$ convencional, foram obtidas usando microdispositivos em vidro com fase estacionária polimérica e LIF como detecção. Trabalhos envolvendo a separação de aminoácidos usando detecção amperométrica normal $^{137}$, amperométrica pulsada ${ }^{138}$ e condutométrica sem contato ${ }^{139}$ foram propostos por diversos grupos.

A análise de carboidratos também tem sido intensamente explorada usando eletroforese em microdispositivos. São as biomoléculas mais abundantes da natureza, desempenham uma ampla variedade de funções e, dessa maneira, o desenvolvimento de metodologias para sua determinação é bastante importante. Vários trabalhos já foram publicados usando diferentes modos de separação e detecção. Entre os métodos de detecção usados para a análise de carboidratos em microdispositivos, a detecção por LIF e eletroquímica são as mais comuns ${ }^{140}$.

Quando comparada à LIF, a grande vantagem do uso da detecção eletroquímica na análise de carboidratos está na não necessidade de derivação das moléculas de açúcar ${ }^{141-144}$. Garcia e Henry ${ }^{141}$ usaram amperometria pulsada em eletrodo de trabalho de ouro para a determinação de açúcares em um microdispositivo construído em PDMS. Em condições otimizadas, obtiveram limites de detecção em torno de 1,2 $\mu \mathrm{mol} \mathrm{L}^{-1}$. Nesse trabalho, para melhores resultados de eficiência e detectabilidade, a separação e detecção foram realizadas em diferentes pHs. Usando amperometria normal, a detecção de carboidratos somente é possível com o uso de eletrodos de co- 
bre $^{142,143}$ e níquel ${ }^{144}$ em meio fortemente alcalino. Separações eficientes de carboidratos, como glicose, galactose, frutose e sacarose, usando hidróxido de sódio como eletrólito de corrida em microdispositivos de vidro, foram obtidas usando esse tipo de detecção por diferentes grupos de pesquisa. Limites de detecção da ordem de $20 \mu \mathrm{mol} \mathrm{L}^{-1}$ foram obtidos ${ }^{143}$.

Dang e colaboradores ${ }^{145}$ separaram misturas complexas de oligossacarídeos derivados de glicoproteínas usando eletroforese de zona em microdispositivos construídos em PMMA. Os oligossacarídeos provenientes das glicoproteínas fetuína, ribonuclease $\mathrm{B}$ e $\alpha_{1}$-ácido glicoproteína foram separados em menos de $100 \mathrm{~s}$ em um microcanal de $30 \mathrm{~mm}$ e detectados por LIF. Usando dextrano clivado enzimaticamente como padrão, o propósito das análises foi mapear os tipos de oligossacarídeos presentes nas glicoproteínas digeridas com uma enzima específica. Trabalhos envolvendo a determinação de carboidratos derivados de glicoproteínas usando microdispositivos com detecção por espectrometria de massas $^{146}$ e absorção no UV ${ }^{147}$ também foram desenvolvidos e podem ser encontrados na literatura.

Finalmente, outra possibilidade de aplicação da eletroforese em microdispositivos é a separação de compostos quirais. Esse tipo de separação em CE ocorre pelo estabelecimento de um equilíbrio dinâmico de interação entre os enantiômeros e um seletor quiral adicionado no eletrólito de separação. Entre os vários seletores quirais já propostos para separações em CE, as ciclodextrinas são as mais comumente empregadas ${ }^{148}$. A seletividade nas interações com o seletor quiral geralmente é bastante baixa devido a grande semelhança entre os compostos. Em CE convencional esse tipo de análise geralmente é feita em capilares com comprimentos grandes e, em grande parte, na ausência de EOF. Assim, as separações quirais em microdispositivos são um desafio bastante grande e relativamente poucos trabalhos são encontrados na literatura ${ }^{149,150}$. Por ex., Schwarz e Hauser ${ }^{149}$ desenvolveram um método para separação de uma mistura de compostos isômeros, relevantes em neurociências, usando um microdispositivo construído em vidro no formato convencional em cruz.

Hutt e colaboradores ${ }^{150}$ separaram isômeros quirais de aminácidos como alanina, lisina, serina e valina usando como seletor quiral a $\gamma$ ciclodextrina. O microdispositivo, construído através de fotolitografia em uma placa de vidro com dimensões de $10 \times 10 \mathrm{~cm}$, teve um microcanal de separação no formato de serpentina com $19 \mathrm{~cm}$ de comprimeto efetivo. Usando como eletrólito de corrida tampão carbonato com SDS/ $\gamma$-ciclodextrina e campo elétrico de separação de $550 \mathrm{~V} \mathrm{~cm}^{-1} \mathrm{em} 10^{\circ} \mathrm{C}$ (para evitar efeito Joule), obtiveram a separação dos enantiômeros com boa resolução em apenas 4 min. A detecção dos aminoácidos derivados foi feita através de LIF. Outros trabalhos de aplicações de microdispositivos em separações quirais foram desenvolvidos e podem ser encontrados na literatura ${ }^{151-153}$.

\section{CONCLUSÕES E PERSPECTIVAS}

Este trabalho aborda o estado da arte referente aos microssistemas de análises químicas. De acordo com as abordagens apresentadas não há dúvidas sobre a viabilidade dos processos de microfabricação, nem sobre a ampla aplicabilidade destes microdispositivos. Esta nova tendência pode ser aplicada a qualquer laboratório químico, nas suas mais diferentes ramificações.

As vantagens relacionadas à confecção dos microchips (tempo de fabricação, ampla variedade de materiais e custo por protótipo), usando diferentes tecnologias de microfabricação (convencionais ou alternativas), bem como ao manuseio de pequenos volumes ( $\mathrm{pL}$ - nL), à possibilidade de integração de múltiplas etapas analíticas em um único substrato e, principalmente, à portabilidade são fato- res que estimulam todos os pesquisadores atuantes nesta ramificação científica. No entanto, os obstáculos que existem na interface entre os mundos macro e microscópio são os desafios a serem superados, de modo a tornar estes dispositivos como ferramentas analíticas efetivas para análise no campo, ou no "point-of-care".

Em resumo, pode-se concluir que os microchips químicos representam uma nova realidade na Química Analítica em âmbito mundial. Um dos propósitos deste trabalho é divulgar esta nova fronteira analítica para a comunidade científica nacional, com a perspectiva de que um número maior de pesquisadores possa contribuir para o progresso desta importante linha de pesquisa no país.

\section{AGRADECIMENTOS}

Ao apoio financeiro da FAPESP e do CNPq pela concessão das bolsas de doutorado, de pesquisa e projetos de pesquisa.

\section{REFERÊNCIAS}

1. van den Berg, A.; Lammerink, T. S. J.; Top. Curr. Chem. 1998, 194, 21.

2. Reyes, D. R.; Iossifidis, D.; Auroux, P. A.; Manz, A.; Anal. Chem. 2002, 74, 2623.

3. Auroux, P. A.; Iossifidis, D.; Reyes, D. R.; Manz, A.; Anal.Chem. 2002, 74, 2637.

4. Vilkner, T.; Janasek, D.; Manz, A.; Anal. Chem. 2004, 76, 3373.

5. Dittrich, P. S.; Tachikawa, K.; Manz, A.; Anal. Chem. 2006, 78, 3887.

6. Madou, M. J.; Fundamentals of Microfabrication, $2^{\text {nd }}$ ed., CRC Press: New York, 2002

7. Ehrfeld, W.; Electrochim. Acta 2003, 20, 2857.

8. Wooley. A. T.; Lao, K.; Glazer, A. N.; Mathies, R. A.; Anal. Chem. 1998, 70,684

9. Terry, S. C.; Jerman, J. H.; Angell, J. B.; IEEE Trans. Electron Devices 1979, ED-26, 1880 .

10. Manz, A.; Miyahara, Y.; Miura, J.; Watanabe, Y.; Miyagi, H.; Sato, K.; Sens. Actuators, B 1990, 1, 249

11. Manz, A.; Graber, N.; Widmer, H. M.; Sens. Actuators, B 1990, 1, 244.

12. Lab-on-a-chip: The Revolution in portable instrumentation, $3^{\text {rd }}$ ed., Frost \& Sullivan Ed.: New York, 1999, p17. (http://www.frost.com/prod/servlet/ frost-home.pag).

13. Gulliksen, A.; Solli, L.; Karlsen, F.; Rogne, H.; Hovig, E.; Nordstrom, T. Sirevág, R.; Anal. Chem. 2003, 76, 9.

14. Chen, Y.; Pépin, A.; Electrophoresis 2002, 22, 187

15. Meyerhofer, D.; J. Appl. Phys. 1978, 49, 3993.

16. Ericson, C.; Holm, J.; Ericson, T.; Hjertén, S.; Anal. Chem. 2000, 72, 81.

17. Lagally, E. T.; Simpson, P. C.; Mathies, R. A.; Sens. Actuators, B 2000, $63,138$.

18. Xiong, L.; Regnier, F. E.; J. Chromatrogr., A 2001, 924, 165.

19. Jacobson, S. C.; Hergenröder, R.; Koutny, L. B.; Warmack, R. J.; Ramsey, J. M.; Anal. Chem. 1994, 66, 1107.

20. He, B.; Tait, N.; Regnier, F.; Anal. Chem. 1998, 70, 3790.

21. Coltro, W. K. T.; Piccin, E.; Fracassi da Silva, J. A.; do Lago, C. L.; Carrilho, E.; Lab Chip 2007, 7, 931.

22. Fintschenko, Y.; van den Berg, A.; J. Chromatogr., A 1998, 819, 3.

23. Schultz, G. A.; Corso, T. N.; Prosser, S. J.; Zhang, S.; Anal. Chem. 2000, $72,4058$.

24. Lao, A. I. K.; Lee, T. M. H.; Sing, I.-M.; Ip, N. Y.; Sens. Actuators, A 2000, 84, 11.

25. Harrison, D. J.; Manz, A.; Fan, Z.; Ludi, H.; Widmer, H. M.; Anal. Chem. 1992, 64, 1926.

26. Wang, H. Y.; Foote, R. S.; Jacobson, S. C.; Schneibel, J. H.; Ramsey, J. M.; Sens. Actuators, B 1997, 45, 199.

27. Mcdonald, J. C.; Whitesides, G. M.; Acc. Chem. Res. 2002, 35, 491.

28. Becker, H.; Gartner, C.; Electrophoresis 2000, 21, 12.

29. Becker, H.; Locascio, L. E.; Talanta 2002, 56, 223

30. Quist, A. P.; Pavlovic, E.; Oscarsson, S.; Anal. Bioanal. Chem. 2005, 381, 591.

31. Martynova, L.; Locascio, L. E.; Gaitan, M.; Kramer, G. W.; Christensen, R. G.; MacCrehan, W. A.; Anal. Chem. 1997, 69, 4783.

32. McCormick, R. M.; Nelson, R. J.; Alonso-Amigo, M. G.; Benvegnu, D. J.; Hooper, H. H.; Anal. Chem. 1997, 69, 2626.

33. Xu, J.; Locascio, L.; Gaitan, M.; Lee, S. C.; Anal. Chem. 2000, 72, 1930.

34. Duffy, D. C.; Mcdonald, J. C.; Schueller, O. J. A.; Whitesides, G. M.; Anal. Chem. 1998, 70, 4974. 
35. Yi, L.; Xiaodong, W.; Chong, L.; Zhifeng, L.; Denan, C.; Dehui, Y.; Microsyst. Technol. 2005, 11, 1272.

36. Xia, Y.; Whitesides, G. M.; Annu. Rev. Mater. Sci. 1998, 28, 153.

37. Whitesides, G. M.; Ostuni, E.; Takayama, S.; Jiang, X.; Ingber, D. E.; Annu. Rev. Biomed. Eng. 2001, 3, 335.

38. Mcdonald, J. C.; Duffy, D. C.; Anderson, J. R.; Chiu, D. T.; Wu, H.; Schueller, O. J. A.; Whitesides, G. M.; Electrophoresis 2000, 21, 27.

39. Whitesides, G. M.; Sia, S. K.; Electrophoresis 2003, 24, 3563.

40. Piccin, E.; Coltro, W. K. T.; Fracassi da Silva, J. A.; Mazo, L. H.; ClaroNeto, S.; Carrilho, E.; J. Chromatogr., A 2007, doi:10.1016/j. chroma. 2007.09.081.

41. Chen, G.; Bao, H. M.; Li, J. H.; Chen, D.; Microchim. Acta 2006, 153, 151.

42. Velten, T.; Ruf, H. H.; Barrow, D.; Aspragathos, N.; Lazarou, P.; Jung, E.; Malek, C. K.; Richter, M.; Kruckow, J.; IEEE Trans. Adv. Packag. 2005, 28, 533.

43. Roberts, M. A.; Rossier, J. S.; Bercier, P.; Girault, H.; Anal. Chem. 1997, 69, 2035.

44. Tan, A.M.; Rodgers, K.; Murrihy, J. P.; O’Mathuna, C.; Glennon, J. D.; Lab Chip 2001, 1,7 .

45. do Lago C. L.; da Silva, H. D. T.; Neves, C. A.; Fracassi da Silva, J. A.; Anal. Chem. 2003, 75, 3853.

46. Coltro, W. K. T.; Fracassi da Silva, J. A.; da Silva, H. D. T.; Richter, E. M.; Furlan, R.; Angnes, L.; do Lago C. L.; Mazo, L. H.; Carrilho, E.; Electrophoresis 2004, 25, 3832 .

47. He, F. Y.; Liu, A. L.; Yuan, J. H.; Coltro,W. K. T.; Carrilho, E.; Xia, X. H.; Anal. Bioanal. Chem. 2005, 382, 192.

48. Liu, A. L.; He, F. Y.; Hu, Y. L.; Xia, X. H.; Talanta 2006, 68, 1303.

49. Coltro, W. K. T.; Fracassi da Silva, J. A.; Carrilho, E.; Electrophoresis, submetido.

50. Liu, A. L.; He, F. Y.; Wang, K.; Zhou, T.; Lu, Y.; Xia, X. H.; Lab Chip 2005, 5, 974

51. Daniel, D.; Gutz, I. G. R.; Electrochem. Commun. 2003, 5, 782.

52. Richter, E. M.; Fracassi da Silva, J. A.; Gutz, I. G. R.; do Lago, C. L.; Angnes, L.; Electrophoresis 2004, 25, 2965.

53. Daniel, D.; Gutz, I. G. R.; Talanta 2005, 68, 429.

54. Bao, N.; Zhang, Q.; Xu, J. J.; Chen, H. Y.; J. Chromatogr., A 2005, 1089, 270.

55. do Lago, C. L.; de Jesus, D. P.; da Silva, H. T. D.; Neves, C. A.; Fracassi da Silva, J. A.; Electrophoresis 2004, 25, 3825.

56. de Jesus, D. P.; Blanes, L.; do Lago, C. L.; Electrophoresis 2006, 27, 4935.

57. Li, M. W.; Huynh, B. H.; Hulvey, M. K.; Lunte, S. M.; Martin, R. S.; Anal. Chem. 2006, 78, 1042.

58. Karling, J. M.; Monahan, J.; Marchiarullo, D. J.; Ferrance, J. P.; Landers, J. P.; Anal. Chem. 2005, 77, 3637.

59. Hisamoto, H.; Horiuchi, T.; Uchiyama, K.; Tokeshi, M.; Hibara, A. Kitamori, T.; Anal. Chem. 2001, 73, 5551.

60. Laser, D. J.; Santiago, J. G.; J. Micromech. Microeng. 2004, 14, R35.

61. Andersson, H.; van der Wijngaart, W.; Nilsson, P.; Enoksson, P.; Stemme, G.; Sensors Actuators, B 2001, 72, 259.

62. Unger, M. A.; Chou, H.-P.; Thorsen, T.; Scherer, A.; Quake, S. R.; Science 2000, 288, 7

63. Figeys, D.; Pinto, D.; Anal. Chem. 2000, 72, 330A.

64. Culbertson, C. T.; Ramsey, R. S.; Ramsey, J. M.; Anal. Chem. 2000, 72, 2285

65. McKnight, T. E.; Culbertson, C. T.; Jacobson, S. C.; Ramsey, J. M.; Anal. Chem. 2001, 73, 4045.

66. Morf, W. E.; Guenat, O. T.; de Rooij, N. F.; Sensors Actuators, B 2001 , $72,266$.

67. Ni, J.; Zhong, C.-J.; Coldiron, S. J.; Porter, M. D.; Anal. Chem. 2001, 73, 103

68. Tas, N. R.; Berenschot, J. W.; Lammerink, T. S. J.; Elwenspoek, M.; van den Berg, A.; Anal. Chem. 2002, 74, 2224.

69. Yin, Z.; Prosperetti, A.; J. Micromech. Microeng. 2005, 15, 643.

70. Chen, G.; Wang, J.; Analyst 2004, 129, 507.

71. Fang, Q.; Anal. Bioanal. Chem. 2004, 378, 49.

72. Backofen, U.; Matysik, F-M.; Lunte, C. E.; Anal. Chem. 2002, 74, 4054

73. Solignac, D.; Gijs, M. A. M.; Anal. Chem. 2003, 75, 1652

74. Martin, R. S.; Gawron, A. J.; Lunte, S. M.; Henry, C. S.; Anal. Chem. 2000 $72,3196$.

75. Alarie, J. P.; Jacobson, J. C.; Ramsey, J. M.; Electrophoresis 2001, 22, 312

76. Jacobson, S. C.; Ramsey, J. M.; Electrophoresis 1995, 16, 481.

77. Jacobson, S. C.; Ermakov, S. V.; Ramsey, J. M.; Anal. Chem. 1999, 71, 3273.

78. http://www.emcohighvoltage.com, acessada em Abril 2006.

79. http://www.matsusada.com, acessada em Abril 2006.

80. Garcia, C. D.; Liu, Y.; Anderson, P.; Henry, C. S.; Lab Chip 2003, 3, 324.

81. Mogensen, K. B.; Klank, H.; Kutter, J. P.; Electrophoresis 2004, 25, 3498

82. Viskari, P. J.; Landers, J. P.; Electrophoresis 2006, 27, 1797.
83. Pumera, M.; Merkoc, A.; Alegret, S.; Trends Anal. Chem. 2006, 25, 219. 84. Wang, J.; Electroanalysis 2005, 17, 1133

85. http://www.chem.agilent.com/Scripts/PDS.ASP?IPage=51, acessada em Setembro 2006.

86. Lacher, N. A.; Garrison, K. E.; Martin, R. S.; Lunte, S. M.; Electrophoresis 2001, 22, 2526.

87. Vandaveer, W. R.; Pasas-Farmer, S. A.; Fischer, D. J.; Frankenfeld, C. N.; Lunte, S. M.; Electrophoresis 2004, 25, 3528.

88. Brito-Neto, J. G. A.; Fracassi da Silva, J. A.; Blanes, L.; Lago, C. L.; Electroanalysis 2005 17, 1198.

89. Brito-Neto, J. G. A.; Fracassi da Silva, J. A.; Blanes, L.; Lago, C. L.; Electroanalysis 2005 17, 1207

90. http://www.chem.agilent.com/Scripts/PDS.ASP?lpage $=38308$, acessada em Setembro 2006.

91. van Bentum, P. J. M.; Janssen, J. W. G.; Kentgens, A. P. M.; Analyst 2004, 129, 793.

92. Bilitewski, U.; Genrich, M.; Kadow, S.; Mersal, G.; Anal. Bioanal. Chem. 2003, 377, 556.

93. Effenhauser, C. S.; Paulus, A.; Manz, A.; Widmer, H. M.; Anal. Chem. 1994, 66, 2949.

94. Liu, S.; Guttman, A.; Trends Anal. Chem. 2004, 23, 422.

95. Khandurina, J.; Guttman, A.; J. Chromatogr., A 2002, 943, 159.

96. Sun, Y.; Kwok, Y. C.; Anal. Chim. Acta 2006, 556, 80.

97. Anderson, H.; van den Berg, A.; Sens. Actuators, B 2003, 92, 315.

98. Wilding, P.; Kricka, L. J.; Cheng, J.; Hvichia, G.; Shoffner, M. A.; Fortina, P.; Anal. Biochem. 1998, 257, 95.

99. Carlson, R.; Gabel, C.; Chan, S.; Austin, R.; Phys. Rev. Lett. 1997, 79, 2149

100. Huang, Y.; Yang, J. M.; Hopkins, P. J.; Kassegne, S.; Tirado, M.; Forster, A. H.; Reese, H.; Biomed. Microdev. 2003, 5, 217.

101. Cui, L.; Zhang, T.; Morgan, H.; J. Micromech. Microeng. 2002, 12, 7.

102. Schilling, E.; Kamholz, A.; Yager, P.; Anal. Chem. 2002, 74, 798

103. Irimia, D.; Tompkins, R. G.; Toner, M.; Anal. Chem. 2004, 76, 6137.

104. Carlo, D. D.; Zanetti, C. I.; Zhang, Y.; Hung, P.; Lee, L. P.; Lab Chip 2005, 5,171 .

105. Taylor, M.; Belgrader, P.; Furman, B.; Pourahmadi, F.; Kovacs, G.; Northrup, A.; Anal. Chem. 2001, 73, 492.

106. Lu, H.; Schimidt, E. L.; Jensen, K. F.; Lab. Chip 2005, 5, 23.

107. Fox, M. B.; Esveld, D. C.; Valero, A.; Luttge, R.; Mastwijk, H. C.; Bartels, P. V.; van den Berg, A.; Boom, R. M.; Anal. Bioanal. Chem. 2006, 385, 474.

108. Verpoorte, E.; Lab Chip 2003, 3, 60N.

109. Chung, Y. C.; Jan, M. S.; Lin, Y. C.; Lin, Y. H.; Cheng, W. C.; Fan, C. Y.; Lab Chip 2004, 4, 141

110. Roper, M. G.; Easley, C. J.; Landers, J. P.; Anal. Chem. 2005, 77, 3887.

111. Legendre, L. A.; Bienvenue, J. M.; Roper, M. G.; Ferrance, J. P.; Landers, J. M.; Anal. Chem. 2006, 78, 1444

112. Hashimoto, M.; Chen, P. C.; Mitchell, M. W.; Nikitopoulos, D. E.; Soper, S. A.; Murphy, M. C.; Lab Chip 2004, 4, 638.

113. Emrich, C. H.; Tian, H.; Medintz, I. L.; Mathies, R. A.; Anal. Chem. 2002, 74, 5076.

114. Ferrance, J. P.; Wu, Q.; Giordano, B.; Hernandez, C.; Kwok, Y.; Snowb, K.; Thibodeau, S.; Landers, J. P.; Anal. Chim. Acta 2003, 500, 223.

115. Soper, S. A.; Ford, A. M.; Xu, Y. C.; Qi, S. Z.; McWhorter, S.; Lassiter, S.; Patterson, D.; Bruch, R. C.; J. Chromatogr., A 1999, 853, 107.

116. Liu, R. H.; Yang, J. N.; Lenigk, T.; Bonanno, J.; Grodzinski, P.; Anal. Chem. 2004, 76, 1824.

117. Sung, W. C.; Makamba, H.; Chen, S.; Electrophoresis 2005, 26, 1783.

118. Rocklin, R. D.; Ramsey, R. S.; Ramsey, J. M.; Anal. Chem. 2000, 72, 5244.

119. Ramsey, J. D.; Jacobson, S. C.; Culbertson, C. T.; Ramsey, J. M.; Anal. Chem. 2003, 75, 3758

120. Shadpour, H.; Soper, S. A.; Anal. Chem. 2006, 78, 3519.

121. Herr, A. E.; Molho, J. I.; Drouvalakis, K. A.; Mikkelsen, J. C.; Utz, P. J.; Santiago, J. G.; Kenny, T. W.; Anal. Chem. 2003, 75, 1180.

122. Griebel, A.; Rund, S.; Schemed, F.; Doerner, W.; Konrad, R.; Hardt, S.; Lab Chip 2004, 4, 18

123. Liu, Y.; Garcia, C. D.; Henry, C. S.; Analyst 2003, 128, 1002

124. Wang, J.; Electrophoresis 2002, 23, 713.

125. Hadd, A. G.; Raymond, D. E.; Halliwell, J. W.; Jacobson, S. C.; Ramsey, J. M.; Anal. Chem. 1997, 69, 3407.

126. Hadd, A. G.; Jacobson, S. C.; Ramsey, J. M.; Anal.Chem. 1999, 71, 5206.

127. Wang, J.; Ibáñes, A.; Chatrathi, M. P.; J. Am. Chem. Soc. 2003, 125, 8444.

128. Gawron, A. J.; Martin, S.; Lunte, S. M.; Eur. J. Pharm. Sci. 2001, 14, 1

129. Willauer, H. D.; Collins, G. E.; Electrophoresis 2003, 24, 2193.

130. Dolnik, V.; Liu, S.; J. Sep. Sci. 2005, 28, 1994.

131. Osbourn, D. M.; Lunte, C. E.; Anal. Chem. 2003, 75, 2710

132. Baldwin, R. P.; Roussel, T. J.; Crain, M. M.; Bathlagunda, A.; Jackson, D. J.; Gullapalli, J.; Conklin, J. A.; Pai, R.; Naber, J. F.; Walsh, K. M.; Keynton, R. S.; Anal. Chem. 2002, 74, 3690. 
133. Muck, A.; Wang, J.; Jacobs, M.; Chen, G.; Chatrathi, M. P.; Jurka, V.; Výborný, Z.; Spillman, S. D.; Sridharan, G.; Schoning, M. J.; Anal. Chem. 2004, 76, 2290.

134. Johirul, M.; Shiddiky, A.; Kim, R. E.; Shim, Y. B.; Electrophoresis 2005, $26,3043$.

135. Munro, N. J.; Huang, Z.; Finegold, D. N.; Landers, J. P.; Anal. Chem. 2000, 72,2765 .

136. Throckmorton, D. J.; Shepodd, T. J.; Singh, A. K.; Anal. Chem. 2002, 74, 784.

137. Wang, J.; Chen, G.; Pumera, M.; Electroanalysis 2003, 15, 862.

138. García, C. D.; Henry, C. S.; Anal. Chem. 2003, 75, 4778.

139. Abad-Villar, E. M.; Kubán, P.; Hauser, P. C.; Electrophoresis 2005, 26, 3609.

140. Suzuki, S.; Honda, S.; Electrophoresis 2003, 24, 3577.

141. García, C. D.; Henry, C.; Anal. Chim. Acta 2004, 508, 1.

142. Schwarz, M. A.; Galliker, B.; Fluri, K.; Kappes, T.; Hauser, P. C.; Analyst 2001, 126, 147.
143. Wang, J.; Chen, G.; Wang, M.; Chatrathi, M. P.; Analyst 2004, 129, 512. 144. Wang, J.; Chen, G.; Chatrathi, M. P.; Electroanalysis 2004, 16, 1603.

145. Dang, F.; Kakehi, K.; Nakajima, K.; Shinohara, Y.; Ishikawa, M.; Kaji, N.; Tokeshi, M.; Baba, Y.; J. Chromatogr., A 2006, 1109, 138.

146. Zamfir, A. D.; Bindila, L.; Lion, N.; Allen, M.; Girault, H. H.; PeterKatalinic, J.; Electrophoresis 2005, 26, 3650.

147. Honda, S.; Suzuki, S.; Taga, A.; J. Pharm. Biomed. Anal. 2003, 30, 1689.

148. Belder, D.; Ludwig, M.; Electrophoresis 2003, 24, 2422.

149. Schwarz, M. A.; Hauser, P. C.; Anal. Chem. 2003, 75, 4691.

150. Hutt, L. D.; Glavin, D. P.; Bada, J. L.; Mathies, R. A.; Anal. Chem. 1999. $71,4000$.

151. Rodríguez, I.; Jin, L. J.; Li, S. F. Y.; Electrophoresis 2000, 21, 211.

152. Piehl, N.; Ludwig, M.; Belder, D.; Electrophoresis 2004, 25, 3848.

153. Gao, Y.; Shen, Z.; Wang, H.; Dai, Z.; Lin, B.; Electrophoresis 2005, 26, 4774. 